A Study of the New York City Milk Problem

By IRWIN G. JENNINGS

Submitted in partial fulfillment of the requirements for the Degree of Doctor of Philosophy in the Faculty

of Political Science, Columbia University. 



\title{
A Study of the New York City Milk Problem
}

\author{
By IRwin G. JenNixgs
}

Submitted in partial fulfillment of the requirements for the Degree of Doctor of Philosophy in the Faculty of Political Science, Columbia University. 


$$
\begin{aligned}
& 5 F 2.58 \\
& .11504
\end{aligned}
$$

Fift

Soivarzit

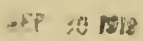




\section{INTRODUCTION}

In the month of September, 1916, the receipt of the daily milk supply of New York City was seriously imperiled. For more than a week, the producers under the leadership of their "association" had been on a strike demanding increased prices from the New York dealers. Much good milk in the possession of those seeking to deliver it to shipping stations was destroyed by the striking producers. A large part of the milk received during this period was not of a sanitary character. A deadlock was reached. The Mayor of the city intervened and tried to settle the dispute, but he made no progress whatever. The dealers were proceeding on the theory that the public would not stand for a rise in the price of milk and their profits were so small that a very slight advance in the cost of milk to them if they were compelled to sell at the then retail prices, would drive practically all of the smaller companies out of business.

The producers were conscious that the price they were receiving from the dealers did not cover the cost of production and so were determined at all events to see the strike through. Beyond the interest taken by the Mayor, there was no authoritative assertion of the right of the New York public to receive its daily supply. The controversy was finally settled, but the public paid the bill. From this time on, the price of milk to the consumer was progressively higher until in November, 1917, but little more than a year from the time of the first strike, grade B milk rose from 9 cents to 15 cents or an advance of $66.2 / 3 \%$ over its former price.

In the fall of 1917, controversy again rose. Public authorities began to take cognizance of the situation and the District Attorney even threatened to indict the leaders of the producers who were making what seemed to him to be exorbitant demands. It was reported that if the District Attorney should carry out his threat against one or more of the members of the Producers' Association, the cows would be killed and the milk destroyed. Again the New York milk supply was imperiled and again the controversy was settled by the New York public's paying the bill.

Something more than a year has passed. In the meantime, the Federal Food Commission which had adjusted the price between the producer and the distributor during the war, after the armistice, dis. continued its efforts along that line. Under the Commission the policy followed was for the dealers to charge their patrons just as much more for their milk as the commission permitted the producers to add to the existing price. Thus both the dealers and farmers got along very nicely at the expense of the consumer. But, in January, 1919, the first month that these two interests in the industry were left to themselves, on account of their inability to agree, a milk strike resulted. There were three conflicting factors in this strike, the dairymen's league, the milk dealers' pool and the New York public. 
The strike was finally settled by the dealers and producers agreeing upon prices for a period of three months, after which time, the questions of future prices will again arise with new possibilities of disagreement.

A number of inquiries and investigations are now under way, some of which have been undertaken by agencies more or less favorable to a particular interest of the industry, and possibly none of them charged with the responsibility of making and justifying constructive recommendations. It would seem therefore, that a most pressing demand has arisen for an unprejudiced inquiry into the facts and the law with a view to preserving the integrity of the milk industry as a whole and of securing both a more economical and uninterrupted service of milk to the New York public. The scope of this study will cover:-

1. Whether or not the health and welfare of the New York public shall be periodically placed in jeopardy by lack of co-operation among the various interests of the milk industry.

2. What is the right of the New York public to an efficiently produced, distributed and controlled milk supply?

3. What are the facts concerning the efficiency of the production, distribution and sanitary control of its milk supply?

4. What results may be expected from the co-operation of the various interests involved and by efficient business organiza. tion throughout the industry?

5. How far should this right be secured by the exercise of the public power?

Greater New York is today a city of more than five million people and growing rapidly. In it there are estimated by the Board of Health to be 130,000 babies under one year of age and 126,000 babies under two years of age. The health, welfare and probably the lives of the greater percentage of these babies are dependent upon an uninterrupted, sanitary milk supply. Besides this, there are a great number of convalescing invalids, some of them wounded soldiers who must have milk. Milk is a vital necessity. There are no satisfactory substitutes for it. The milk supply cannot with impunity be tampered with. To do so may mean death to many human beings. To be the direct or indirect cause of a single death means more than fines or jail to the guilty person. The New York public's right to life and health is fundamental. There are some things about which the interests may quarrel, but their quarrels should not be allowed to imperil the lives of the people.

Although New York City will always be dependent upon the outside world for its food and drink, it has an undoubted right to them which should not be interfered with even if drastic penal legis. lation is necessary to emphasize it. It is reasonable to expect that its milk supply will be received at a cost to the public which contemplates only a reasonable profit after it has been efficiently produced, distributed and controlled. If milk is a vital necessity and is 
universally used by the New York public, then its production, distribution and control become very like public service functions and whoever is engaged therein is accountable to the people for their proper and efficient performance and any extraordinary profits derived therefrom.

- But those so engaged, whether as producers, distributors or as controlling agents, are entitled to be treated as public service agents and to receive credit and a fair profit for the service rendered and for the capital loaned to the public, providing their work has been efficiently done and their capital efficiently used. For a number of years a fair profit has not been accorded either to the milk producer nor to the milk distributor. This fact has been evidenced by the unrest that has existed in the country among the producers and the large number of distributors who have been forced out of business. To run a dairy farm successfully, requires brains and understanding, investment of capital and a sympathetic attitude towards sanitary regulations. Why should it not pay the farmer to meet these conditions? To administer a great milk business in New York City with its various responsibilities and with the great variety of business and sanitary functions to be performed, is worthy of a profit commensurate with self-respect and with financial health. Thereiore, before the more drastic features of the public power are brought to bear upon the milk industry or before the public irrevocably assumes the responsibility of owning and running an industry of such great magnitude, the opportunity should be given for the various interests of the milk industry to co-operate upon a basis where all can see a reasonable profit and where there will still be present the stimulus of additional financial reward for the intelligent use of efficient business organization and of business methods throughout the industry.

No interest in the milk industry has in the past sufficiently appreciated the dignity, importance and responsibility of the functions it has been performing. To this fact is due most of the disrepute into which the industry has fallen. The public attitude and that of the press toward the industry have been wrong. The milk distributor, instead of being looked upon as a business man performing a public service function and entitled to credit for work well done, has been universally regarded with suspicion. The presumption has been against him. No morsel of news has been so luscious, in the eyes of the ordinary reporter, as a front page account of adulteration or dirty containers or of responsibility for disease traced to a milk dealer's door. It has been popular pastime for the social reformer to attack the milk dealer and to charge him with fraud, dishonesty and uncleanliness, and the latter has had well defined reasons for taking a position calling for the least possible publicity.

The court records have been against the dealer and as they stand the presumption is fairly adverse. But these records are not a fair index of the true situation. The following compilations made by the New York Milk Committee, of which the 1914 figures have never been published, are interesting on this point. 


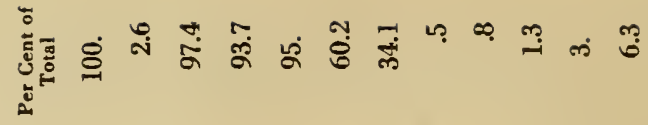

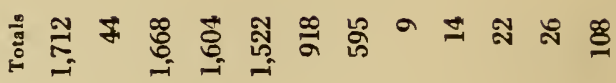

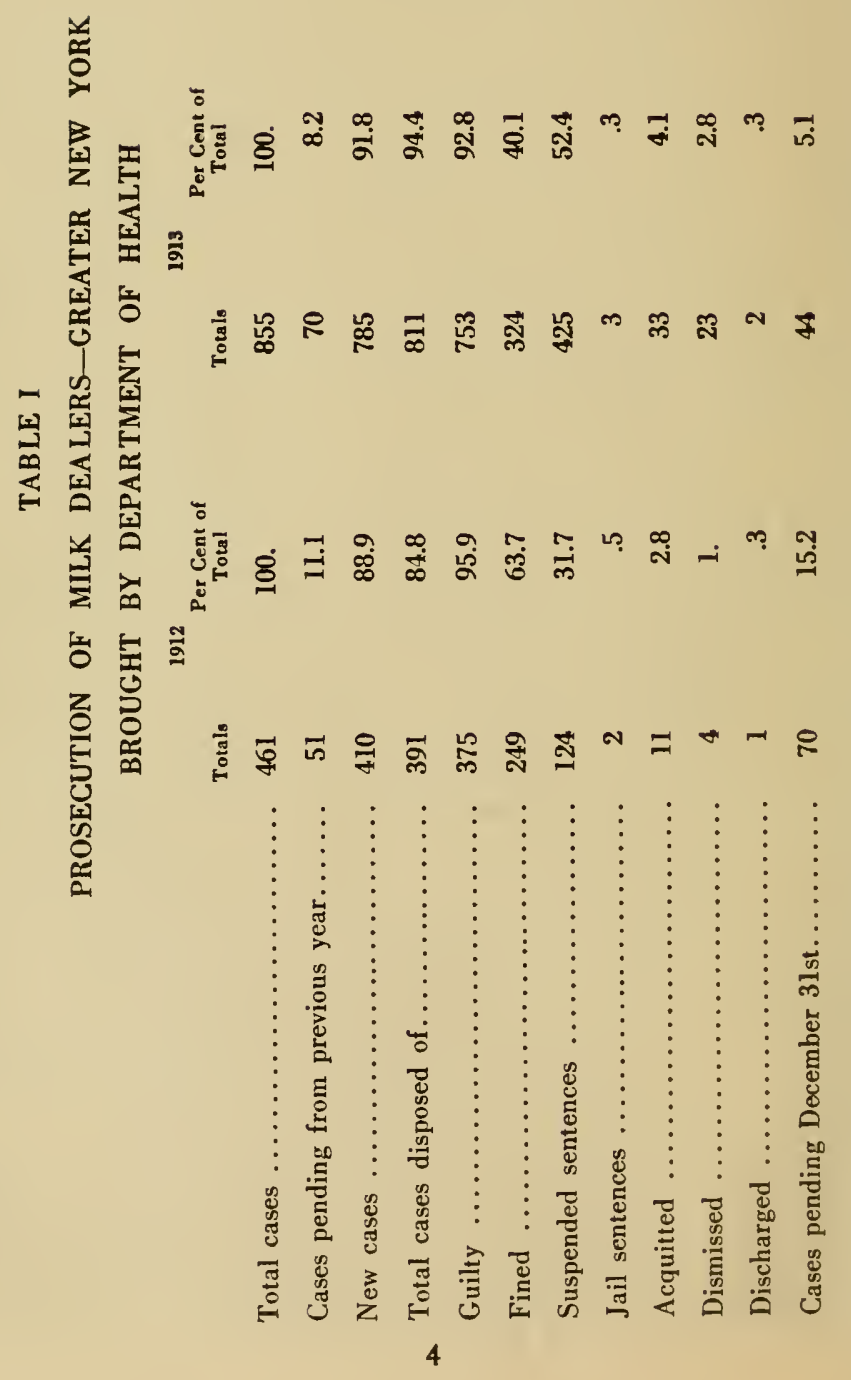




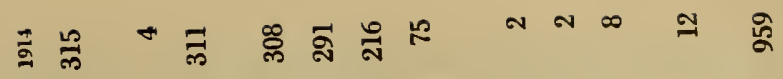

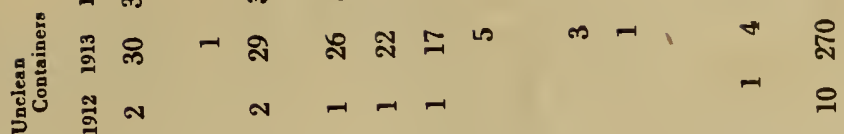

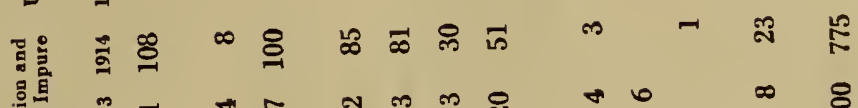

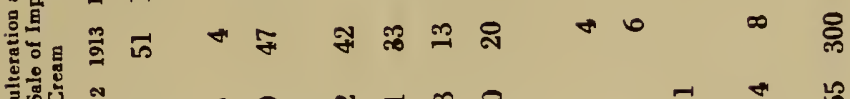

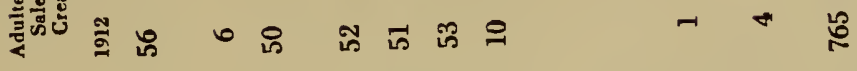

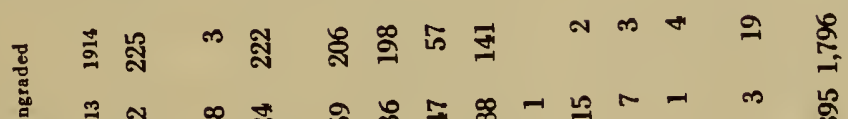

$$
\begin{aligned}
& \text { 范 } \\
& \text { 膀 }
\end{aligned}
$$

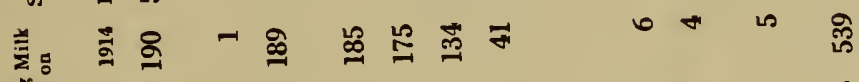

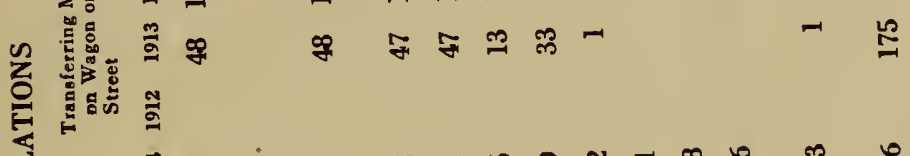

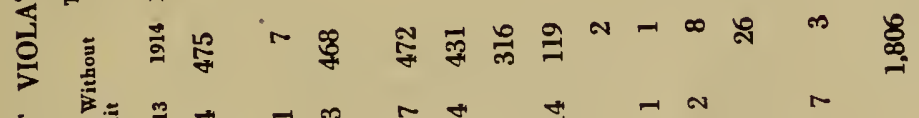

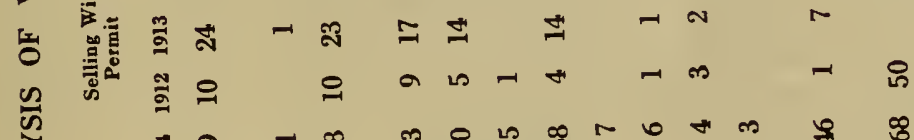

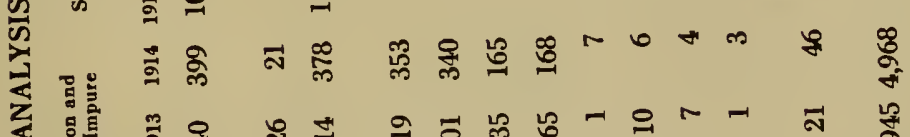

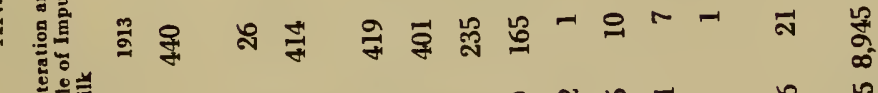

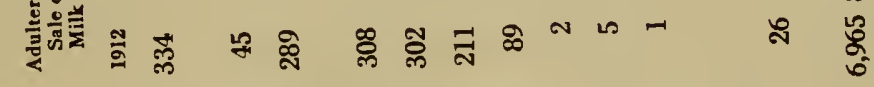

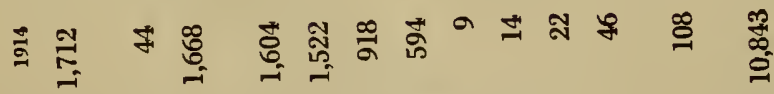

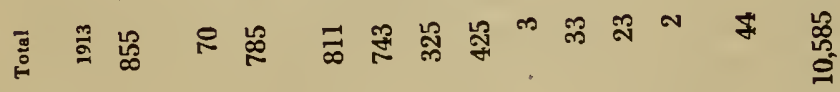

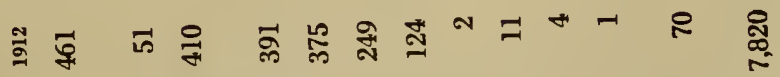

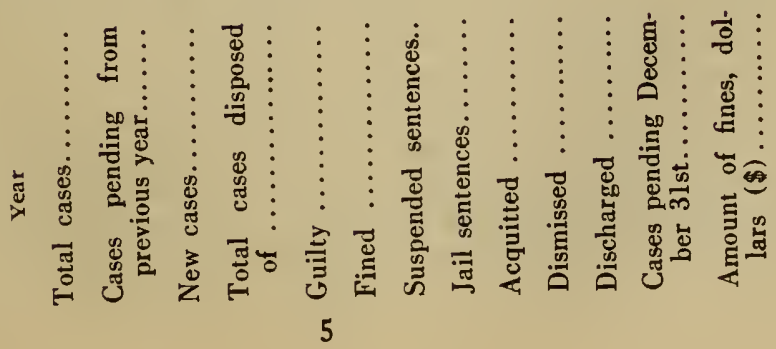


Under the first analysis above, it will be seen that on an average, in $94 \%$ of the prosecutions, the dealer was found guilty. If the same number of criminal prosecutions were brought against other citizens with the same financial ability possessed by these milk dealers to hire attorneys and carry the cases through the courts and where the rule obtained that conviction must be on evidence beyond a reasonable doubt, a much smaller percentage of convictions would be shown. But from the business standpoint, the milk dealer could not afford to fight this type of prosecution as he would others. The limited number of jail sentences and of fines imposed, as shown above, together with the small amount of publicity incurred by this course, justified him in his attitude.

Under the analysis of violations, the very nature of two of the charges would seem to designate the milk dealer as an unfit public servant. Adulteration of milk and unclean containers bring before our eyes a most condemning picture; but when we remember that most of the cases of adulteration were based upon the conclusive presumption, that milk below the legal standard in butter fat, is adulterated, notwithstanding the fact that at certain seasons of the year in New York state, milk directly drawn from many of the cows is below such standard, the crime is not so terrible after all. When it is further understood that if a milk driver receives a dirty bottle from a house wife and it is found in his possession, that there is no evidence that can refute the presumption of his guilt in using unclean containers, the difficulty of his position is apparent. On the other hand, this non-resistance on the part of the milk dealer has encouraged the courts to construct the above legal presumptions against him that would not be tolerated in other cases.

The good will of a milk business is its main asset. The milk plants, the machinery, the wagons and the cans of a concern that is not going are worth but little. To preserve the good will is most important. The most effective menace to this good will is unfavorable newspaper notoriety. To keep his cases out of the general courts has been considered by the milk dealer, essential in order to escape such publicity. To plead guilty and to take reprimands in the minor courts accomplished this purpose. While in the interests of public health, such matters as penalizing a milk dealer for real adulteration and for a criminally careless use of dirty containers are well within the scope of the police power, it is also a fact that herein this great public power has often been used to affect detrimentally the morale of an important branch of the milk industry.

The application of the power itself is not to blame, but the attendant attitude of the public through its agents of publicity and justice has exercised a most repressive influence. Over-regulation can be so used as to deprive New York of its milk supply, or, on the other hand, its more constructive use may be used to insure a better and more wholesome product. At one extreme, there can be invoked intelligent, constructive, stimulating regulation, at the other, 
repressive and destructive prosecution. Any governmental regulation, however slight it may be and though it may insure co-operation and efficiency throughout the industry, will necessarily have to be applied under the sanction of the police power. The more intelligent the regulation, the more in harmony it is with the basic needs of the industry and the more stimulating and effective it will be.

The following study of the milk industry will seek to show certain inefficiencies throughout the industry and their causes together with some constructive suggestions as to remedies. While recognizing the ability of the New York public to assume the ownership of the milk industry and the moral and legal grounds for the regulation thereof by a state commission, it will urge as the better alternative the value of co-operation between the conflicting interests of the industry, the continuance of a proper division of labor, the necessity for faith in each other's honesty of purpose and a proper appreciation by all concerned of the important element of service in producing and distributing clean milk to the world's leading city.

In submitting the tables contained in the following chapters, no attempt will be made to claim for them a greater scientific value than appears on their face. They are generally based upon an analysis of a considerable amount of data gathered on a certain day or covering a short period of time. The time selected to gather most of this data was in the early part of December, 1917, during ap. proximately normal production in the country and before the con. solidations which have been so largely in vogue among the dealers during the past year, had greatly affected the industry. An analysis of data covering longer periods of time might have been made, but the variations due to prices, locality, types of cattle and other matters would still affect its scientific accuracy. On the other hand, a study covering a shorter period is valuable as showing the tendencies and relations, because a larger number of facts can be gathered, which so far as they go, are more likely to be accurate and will not mislead unless they are mislabeled.

\section{CHAPTER I.}

\section{Inefficiencies in Production.}

The basis of the whole milk industry is production. It would seem, therefore, that every branch of the industry would naturally be influenced greatly by production processes and organization and that production must be intelligent, efficient and sufficient. All other branches of the industry are dependent upon the producer. This does not mean that the producer should control these other branches, but it is most necessary that he work with them and they with and for him. The producer should be the first to welcome co-operation and the other interests in the business must be persuaded to voluntarily or involuntarily co-operate with him. 
According to Board of Health Reports the milk supply of New York City is obtained from more than 30,000 farms in six different states and Canada, although more than three-fourths of the supply under normal conditions comes from New York State alone. It can easily be seen that in a production process where there are more than 30,000 bosses with almost as many different ideals and attitudes towards production, great efficiency therein can scarcely be expected. But much can be done to make conditions better. The same business principles obtain in the production of milk as in other lines of production. Such fundamentals as centralization of control can only come with association and regulation. But much can be done through educational processes to arouse a realization of the im. portance of the industry and to promote among its several interests a mutual faith and confidence in each other.

The principle causes of inefficiency in milk production are:

First. Treating it as a side line. Many dairymen seem to evince no interest or enthusiasm in the production of milk as a science or a business. It is a fundamental principle that no man can expect to succeed in any business or profession in which he does not believe and into which he can not put his heart.

Second. The failure to use ordinary business methods in the production of milk. All well organized branches of production contemplate at least three things, capacity production, the use of reasonable accounting methods which will show the relation between the cost of the articles produced and their price, and a constructive purpose governing the production processes. One or more of these business fundamentals are generally absent in the production of milk.

The ordinary milk producer seldom looks upon his farm as a producing plant carrying with it a certain fixed overhead which may become more or less destructive according to the way his farm is used. In dairying, there certainly must be a relation between the number of acres in the farm, the amount of capital invested in buildings, the amount of additional capital that can be applied to the farm economically, the number of cows maintained and the amount of milk produced. In contemplating the amount of capital to be expended in buildings and cows, the availability and proximity of the farm to the market or shipping station should be considered and the question asked and answered as to whether such distance may not preclude its ever becoming the proper site for a profitable dairy. If so, common sense would seem to dictate that the foundations of a producing dairy should not be laid upon such a farm.

As to the consideration of reasonable accounting, there is no question but what this is vital to the successful dairy. No amount of argument or sentiment will justify the maintenance of a cow that will not produce her feed in milk and yet experience is showing that there are thousands of such cows which are not known to be such. Of course, if all the unproductive cows were killed at once, a milk shortage would follow. But practically, there is no such danger 
and much may be gained by an intelligent examination of the herds and a determined effort put forth to eliminate unprofitable cows and to breed for more profitable production. The very great chances are that boarders will beget boarders and so the same old inefficient cow organization is maintained from year to year.

Of very great importance is the third principle, that of having a really constructive purpose in mind in organizing for better dairying. Such a purpose will provide for accounting and for the elimination of boarders, and for breeding the herd toward a profitable production basis. Such a purpose will give character to the whole farm and everyone and everything connected with it. It is the big requisite for success in any industry and no less so in the production of milk. All the inspiration that comes to the successful man in any business, may be felt by the dairymen. Dairying is even better in this respect than successful farming.

In the Fall of 1914, the writer, as Secretary of one of New York's larger milk companies, attended the National Dairy show at Chicago on the theory that here would be a good place to study cows. Much to his satisfaction, he found that there were plenty of cows to be studied. He addressed himself to the owners of the various herds of pure bred stock and was treated with great courtesy. They showed him their prize cows and all their good points, and they answered all his questions.

The next day he repaired to the ground floor where the prize stock was being judged and watched this process with great interest, prejudging the cows himself with varying success. But after spending several hours at this he felt dissatisfied with his progress for the reason that these cows were of the purest type and the best in their class, whereas the type of cow, the study of which would be most valuable to him was the ordinary grade cow that would commonly be found in the New York territory. He went up into the barns again and there is one corner he found exactly what he wished most to see. The United States government was making a public demonstration of the relation which exists between cows and their feed, and the amount and value of milk produced and had chosen for the purpose nine common grade cows of dissimilar types.

The writer stayed with this herd of cows during the remainder of the show and assumed to himself all the functions of ownership, watching their feeding, their milking and the preparation of the records, also inquiring specifically into the history of the cows and the manner of their acquisition by the government superintendent. He found that his herd consisted of some very good cows and of some decidedly unprofitable ones. 
TABLE II

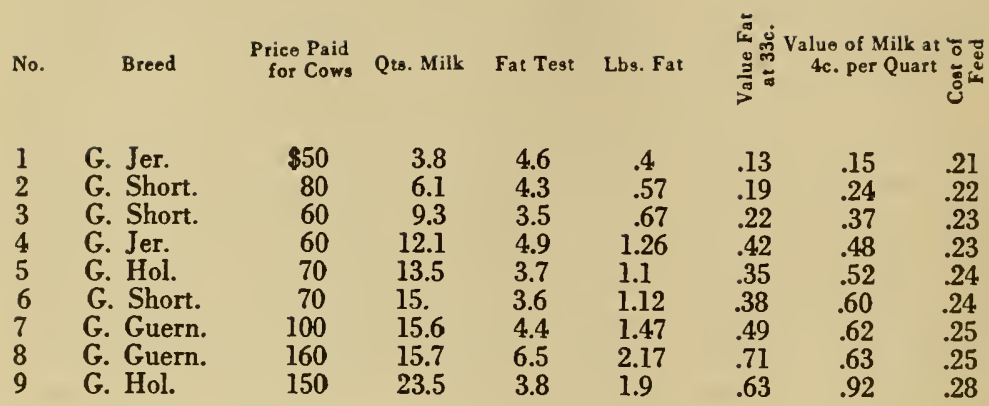

The appended table is the average record for each cow during the week's experience. The cows were about the same age and freshened at or near the same date. On the basis of fat value, some of them did not even pay for their feed, let alone the overhead and other expenses that would have to be accounted for as the basis of farm production cost. On the per quart basis, calculated at $4 \mathrm{c}$ per quart, the average price to the farmer at that time, the showing was but little better. The last day spent at the show was the most illuminating to the writer. Although he himself knew from his observation the relative productive value of these cows, he wanted to gain some idea of the ability of those, especially dairymen, who visited the exhibit to judge the value of the different cows in the herd, before they knew the facts. As the cows were to be sold at the close of the show, he asked various visitors at the exhibit to assist him in appraising the value of the animals. At least a score of practical farmers, dairy experts, and agricultural writers, after careful examination, appraised the cows, but no two of them agreed in their estimates nor correctly adjudged them according to their respective showings in the demonstration. Much surprise was manifested when the facts were learned. Practically all agreed that number 9 was a high grade cow, but as to the others there was a great diversity of opinion, one man valuing number 1 above number 8 , the estimates of which latter cow varied from beef to $\$ 100.00$. The reasonable conclusion from this experience would seem to be that the average farmer or dairyman does not and probably cannot know whether or not a dairy cow will prove to be a profitable milk producer by mere physical inspection and without keeping an actual account of her production as compared with the cost of her main. tenance during a sufficient period of time to learn the facts. 
TABLE III

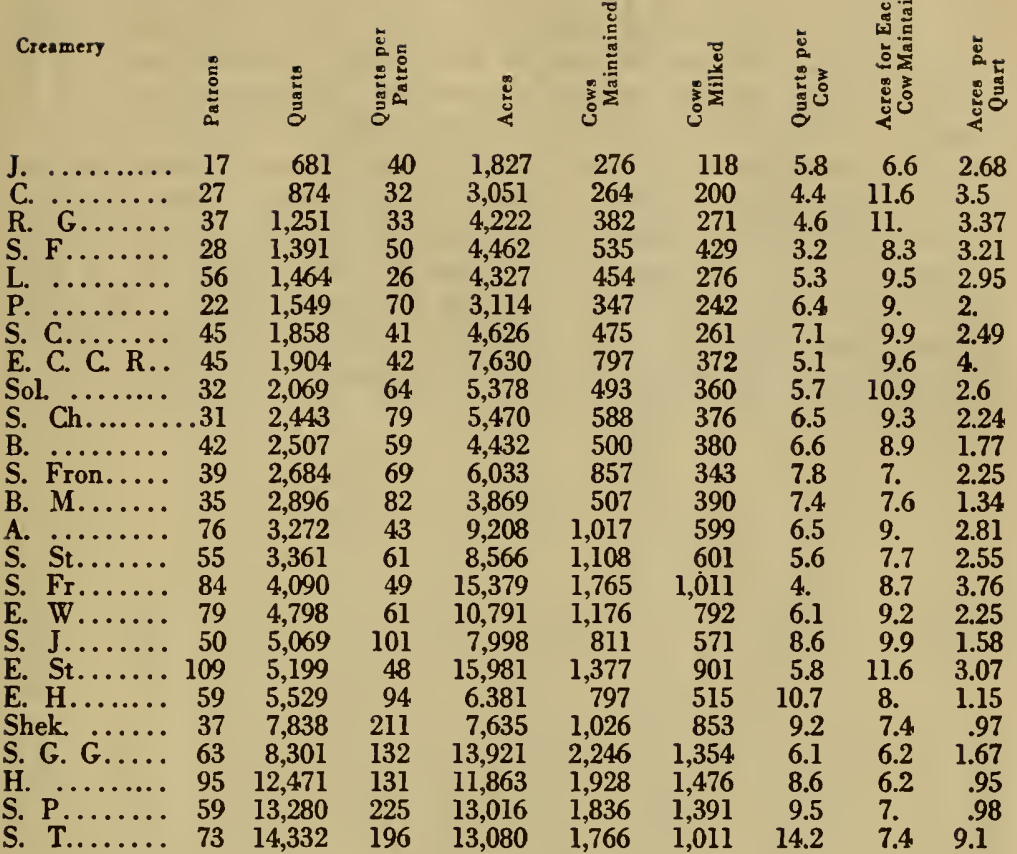

Table number three is based upon answers returned to a ques. tionnaire submitted to 25 superintendents of creameries or shipping stations of various sizes located in different sections of the New York territory and performing various functions. The answers were carefully prepared by the creamery superintendents from their records, their observations and from interrogating their patrons on the day in question. The attempt has here been made to show the relations existing between the patrons at each creamery and the amount of their production, also between the cows maintained and the cows milked by them, between the acres owned and the cows maintained and between the cows milked, the quarts per cow and the acres per quart. Data covering the individual patrons of each creamery was gathered and the above relations for each individual shown, the table itself showing only the average situation existing at each creamery.

The table gives the figures for the production of a single day in December, 1917, on 1,295 farms, consisting of 192,260 acres, maintaining 23,238 cows, of which 15,093 or about $65 \%$ were being milked at the time, and producing on that day 111,111 quarts of milk, which was about $1 . / 15$ of the total milk supply of New York City for that day. 
The size of the creameries varied as to patrons from 17 to 109 and in amount of their receipts for the day from 681 to 14,332 quarts. The average amount of quarts delivered to the creameries on that day was 86 , a little more than 2 cans, although the actual average for one of the creameries was as low as 26 quarts for each of 56 patrons, while another creamery averaged 225 quarts each for 59 patrons. The average amount of milk given for each cow milked was 7.3 quarts, while at one creamery the average production per cow was but little over three quarts. The average production per cow of nine of the creameries was under 6 quarts per day, which amount has been estimated to be about the average amount of milk given per cow in New York State on the yearly basis. The table further shows that 8.2 acres of land on the average were used for the maintenance of each cow, while it required 1.8 acres of land for each quart of milk produced.

\section{TABLE IV}

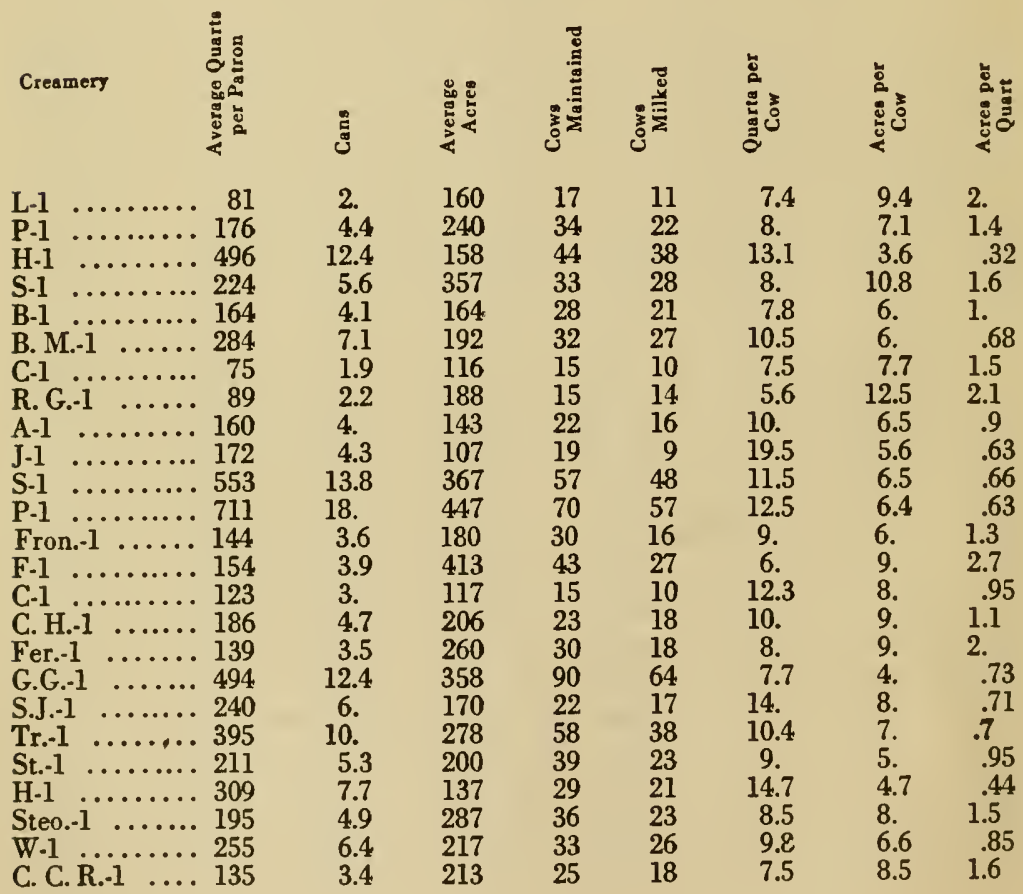


TABLE V

\begin{tabular}{|c|c|c|c|c|c|c|c|c|}
\hline Creamery & 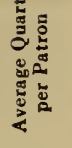 & క్ & 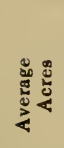 & 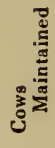 & 串 & 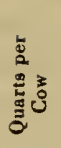 & 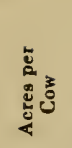 & 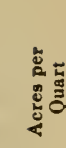 \\
\hline L-2 $\ldots \ldots \ldots$ & 5 & $1 / 8$ & 57 & 4 & 2 & 2.5 & 14. & 11.4 \\
\hline $\mathbf{P}-2 \ldots \ldots \ldots$ & 34 & .9 & 105 & 10 & $\overline{7}$ & 4.8 & 10. & 3. \\
\hline $\mathrm{H}-2 \ldots \ldots \ldots$ & 10 & .25 & 97 & 13 & 6 & 1.7 & 7.5 & 9.7 \\
\hline S $-2 \ldots \ldots \ldots$ & 12 & .3 & 87 & 9 & 5 & 2.4 & 9.7 & 7.3 \\
\hline ........ & 15 & .37 & 99 & 10 & 7 & 2.1 & 9.9 & 6.6 \\
\hline B. M. $-2 \ldots \ldots$ & $8 \mathrm{r} / 3$ & .2 & 36 & 5 & 5 & 1.8 & 7.1 & 4.3 \\
\hline $\mathrm{C}-2 \ldots \ldots \ldots \ldots$ & $8 \mathrm{r} / 3$ & .2 & 110 & 7 & 4 & 2.2 & 16.5 & 13.2 \\
\hline R. G.-2 & 9 & .22 & 54 & 5 & 3 & 2.7 & 10.9 & 6. \\
\hline A-2 .. & $81 / 3$ & .2 & 103 & 13 & 3 & 2.5 & 7.7 & 12.4 \\
\hline ....... & 23 & .57 & 68 & 11 & 4 & 5.8 & 6.4 & 3. \\
\hline .......... & 30 & .75 & 183 & 11 & 7 & 4.5 & 16.6 & 6.1 \\
\hline P. $2 \ldots \ldots \ldots$ & 30.4 & .75 & 135 & 12 & 7 & 4.3 & 11.2 & 4.4 \\
\hline Fron.-2 $\ldots \ldots$ & 12.5 & .3 & 97 & 8 & 2 & 6.2 & 12. & 8. \\
\hline F.2 $\ldots \ldots$ & 9.4 & .23 & 101 & 10 & 6 & 1.6 & 10. & 11. \\
\hline $\mathrm{C}-2 \ldots \ldots$ & 5.5 & .14 & 87 & 7 & 2 & 2.8 & 12.4 & 16. \\
\hline C. H. $-2 \quad \ldots \ldots$ & 14 & .35 & 107 & 7 & 6 & 2.3 & 15.3 & 7.6 \\
\hline Fer. $2 \quad \ldots \ldots$ & 12.5 & .3 & 115 & 13 & 5 & 2.5 & 9. & 9. \\
\hline G.G.-2 $\ldots$ & 22.4 & .56 & 103 & 17 & 7 & 3.2 & 6. & 4.6 \\
\hline S. J..2 $\ldots$ & 11.1 & .28 & 140 & 9 & 5 & 2.2 & 15.5 & 12.6 \\
\hline Tr.-2 ... & 9.5 & .24 & 108 & 11 & 6 & 1.6 & 9.8 & 11.3 \\
\hline St. 2 . $\ldots \ldots \ldots$ & 10.9 & .27 & 51 & 7 & 5 & 2.2 & 7.3 & 4.7 \\
\hline & 21.2 & .53 & 29 & 4 & 3 & 7.1 & 7.3 & 1.3 \\
\hline Steo.-2 ...... & 9 & .23 & 88 & 10 & 3 & 3. & 8.8 & 9.8 \\
\hline & 9 & .23 & 101 & 10 & 4 & 2.2 & 10.1 & 11.2 \\
\hline C. C. R. $-2 \ldots$ & 8 & .2 & 172 & 11 & 4 & 2. & 16. & .22 \\
\hline
\end{tabular}

Table number 4 is made up of the same day's figures for the three largest producers in each creamery and table 5 from the three smallest producers, no attention being paid to the question of efficiency in production except so far as was indicated by the amount of production. Table 4 contains the average showing of 75 large producers, while table 5 contains the average of 75 small producers. As in the one case, the average number of quarts produced per patron is much larger, so in the other case, the average amount is much smaller than a like average for all the patrons in their respective creameries. Certainly one would expect to see a different type of farm producing 246 quarts per patron than one producing 14. quarts and would also expect a different amount of profit per quart.

The figures are rather illuminating, however. The cows of the large producers gave on the average 9.93 quarts per cow, while 6.6 acres were used for the maintenance of each cow and less than one acre of land was required to produce one quart of milk. The cows of the smaller producers gave on the average, less than three quarts of milk, requiring more than ten acres of land to produce one quart of milk. It will be noted at creamery J-1 more than 19 quarts of milk were produced per cow, while in table 5 the average of the 
producers at four creameries was less than two quarts per cow. Of the large producers, all but one was up to the average of the New York State production per cow, while in table 5, at only two cream. eries was the average number of quarts per cow up to the average state production per cow. Yet the average number of acres owned by these smaller producers was 97 and the average number of cows maintained by each was ten. It is obvious that if the price of milk is determined, so as to permit a reasonable profit for the average New York producer, very many other producers will be making from less than a reasonable profit to a positive loss, not because they have not the cows, nor the acres, nor the shipping facilities, but because of a lack of interest or the application of business methods to their dairying.

For a determination of efficient production of milk, it is abso. lutely necessary to take four things into consideration, first, the size and character of the farm and the relative number of cows upon it, second, the productivity of the separate cows, third, the efficient administration of the farm and the amount of emphasis placed upon dairying as a business, fourth, the distance of the farm from the creamery or shipping station; although this latter point will be considered in the discussion under the head of milk delivery. Compilations of figures which fail to take into consideration these elements may be interesting and valuable, but are inconclusive. The Wicks Committee found after months of investigation that the average production of New York State was between 4,000 to 4,500 pounds, or from 1,882 quarts to 2,118 quarts per year, or between 5.2 and 6 quarts per day. This Committee found that the cost of producing 4,695 pounds was $\$ 107.67,5,886$ pounds was $\$ 124.63$, 8,500 pounds was $\$ 150.75$. From these figures it is plain that the cost of keeping cows does not vary proportionately according to the amount of their production. In table number 2 it will be seen that the cost of maintaining the best cow, which gave more than six times the amount of milk of the poorest cow, was only $28 \mathrm{c}$ per day, while that of the poorest cow was 21c. So that the argument is irrefutable, that it will pay the farmers of New York State to seek, acquire and breed better production stock.

Now what is to be done in the matter? The reasonably efficient dairyman has a right to a reasonable profit for his milk, but just as the inefficient business man, no matter what may be his business or where he may be found, neither makes a profit nor is entitled to make a profit, so a price should not be demanded for milk which will assure a profit to the inefficient milk producer, especially where the burden falls on the innocent consumer.

But efficient production is entitled to a profit and milk is entitled to the price rating commensurate with its value as a food. This means that both the production and the price must be right. Similarly both the public and the producer are entitled to the most 
efficient distribution organization that can be devised. Production of milk is a great and honorable business in itself and is worthy of the undivided and best efforts of any man who engages in it. Whatever the method of distribution, it is also worthy of expert and undivided attention. Since both production and distribution are distinct functions of the milk industry, but each dependent for industrial health on the other, the maintenance of a proper division of labor based upon co-operation and fair dealing is essential to industrial progress and the public service.

Each creamery should become an educational dairy center where the best interests of the producer, distributor and consumer are freely discussed. The distributor, as the business agent of the industry, should initiate and encourage co-operative buying on the basis not of profits to himself, but of a saving to his patrons. Cow testing associations should be provided for and encouraged. Quantity and uniform production should be stimulated by premium payments added to the market price and every effort of both distributors and producers and of such agencies as may represent the public should be contributed to make dairying what it deserves to be, the greatest, most interesting and most profitable of our food industries. In all this, work well done should have the support and plaudits of the press and all other public agencies. Every regulatory agent should know the industry from the bottom up and be dominated in his work by the ideals commensurate with the dignity of his task. Such a policy is possible and will make a satisfied and prosperous producer, a happy consumer and an enthusiastic distributor.

\section{CHAPTER II.}

\section{INEFficiency in the Delivery of the New York Milk Supply.}

In contemplating the inefficiencies of the milk industry, it is generally assumed that the delivery of milk in New York City is especially subject to this criticism; in fact with most people that is about as far as the considerations of inefficiency in the industry go. Practically everybody has observed a number of milk delivery wagons on his residence block and naturally asks himself if such duplicate deliveries are not inefficient. The writer himself has heard it said several times that there were seventeen wagons delivering milk on every block in New York City, although the basis for this conclusion was not given. Since city delivery is one of the functions of the milk dealer, his branch of the industry is apt to bear more than its share of the popular charges of inefficiency. It becomes, therefore, a matter of great interest to inquire just what inefficiencies exist in the delivery of milk, and as its delivery starts from the cow and ends with the consumer, our study will begin with the delivery of milk by the farmer to the shipping station or creamery and will end with its receipt by the consumer in New York City. 
Inasmuch as the distance of the farm from the shipping station is a factor to be considered in connection with the desirability of the farmer's producing plant, it might be equally as logical to consider country delivery as a production or first cost item. But while keeping this in mind, it will here be treated as part of milk delivery. The same process of getting the facts bearing upon country delivery was used as in obtaining the production facts in table three of the chapter on the inefficiencies of production, that is, the actual facts as they existed on the day of inquiry were obtained through questions submitted to the creamery superintendents. The answers to these questions are certainly very interesting and are tabulated in table 6 , the purpose being to ascertain the relation existing between the amount of milk delivered to the creamery and the number of men, wagons and horses used for such delivery.

The superintendents were also asked to make the following estimates:

First, if the Company will give you the contract for bringing all of the milk delivered to your creamery within the hours required for properly preparing for shipment, how many horses, wagons, trucks or automobile trucks in detail would you use? Second, if the farmers living within easy access to one another would co-operate in bringing their milk to the creamery, how many groups could be economically formed and how many wagons, trucks, etc., now used could be displaced.

While a few of the superintendents did not give these estimates, enough responded so as to convince one that much may be done to simplify the delivery of milk by the farmer to the creamery and thereby eliminate some of the original cost elements which the consumer is ultimately required to pay.

Before examining table 6 it will again be well to keep in mind that the writer is not claiming anything more for these tables than appears on the face of them. This table gives the delivery experience accurately and positively for a day certain. It can do no more than show a tendency. An examination of the matter has shown that about half these creameries were receiving in the neigh borhood of their average number of quarts for the year. Others were below and still others above the average, but the estimates made by the superintendents were generally on the basis of bringing to the creamery throughout the year the milk produced, regardless of amount. The number of patrons in any event remains practically fixed while the organizer of a co-operative delivery system would be more concerned with the number of stops and the location of the various groups of producers than with the amount of milk received. 
TABLE VI

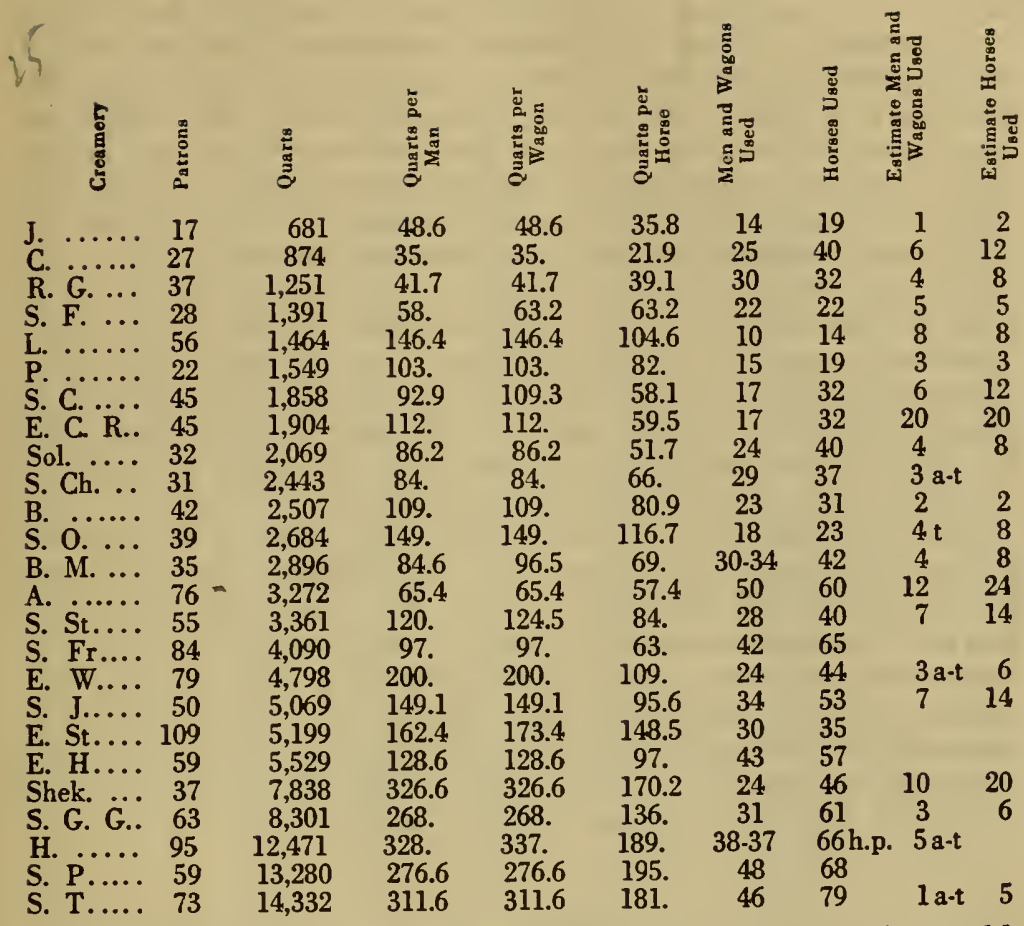

There are some very interesting observations to be made in table 6. Take for instance creamery $\mathrm{C}$, the second on the list where $\mathbf{8 7 4}$ quarts or less than 22 cans were received on the day in question. At a well organized creamery, 20 cans of milk are often received from one wagon with one driver and two horses; yet in this case, 22 cans required 25 men and 40 horses. Further down the list, it will be noted that creamy "Shek," which received on the same day 7,838 quarts of milk, more than nine times the above amount, required one less man and only six more horses and the "Shek" superintendent thinks he could bring in this same quantity of milk from his 37 producers with 10 men and wagons and 20 horses, less than half of those actually used. It is also interesting to note that the superintendent at $C$ creamery thinks that he could bring in the milk at his creamery with 6 men and wagons and 12 horses, thereby eliminating 19 men and 28 horses.

Take the case of A creamery about half way down the list. Here 50 men and wagons and 60 horses were used to bring to the creamery that which the superintendent thinks he could gather up and deliver on time for preparation and shipment with 12 men and wagons and 24 horses, thereby saving the labor of 38 men and 36 
horses. Here considerably more man power and only a little less horse power were used on this day than to make the delivery of 12,471 quarts at creamery $\mathrm{H}$, where the superintendent believes he could gather in the milk with five auto trucks. Or take for example the case of Creamery J, the first creamery on the list, where the superintendent thinks he could do with one wagon and two horses what is now being done with 14 men and wagons and 19 horses, and similarly creamery B. M. just above creamery A. Take the case of 16 of these creameries whose superintendents presented estimates of the number of men, horses and wagons they would require if organizing the delivery of milk to their respective creameries for profit to themselves under competitive bidding. Where the present delivery requires in the aggregate 398 men and wagons and 583 horses, their combined reports show that the same delivery could be made with 102 men and wagons and 166 horses, thus presenting a saving of $74 \%$ in men and wagons and $71 \%$ in the number of horses. Or, figuring on the basis of the work actually being done on the superintendents' estimates, the delivery of the producers' milk to these creameries now requires three times as many men and wagons and two and a half times as many horses as is necessary. Or, for specific information, take the case of B. M. in table 6. Here the superintendent, the best posted expert on delivery facts in his community, estimates that he can do with 4 men and wagons and 8 horses what now requires seven and a half times as many men and wagons and five and a half times as many horses as is necessary.

TABLE VII

Creamery

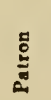

S. ...........Mr. B.

S. $\ldots \ldots \ldots \ldots \ldots$ Mr. B.

B. M. .......Mr. G.

B. M. $\ldots \ldots \ldots \ldots$ Mr. J.

R. G. ......... Mr. W.

A. ............ Mr. D.

A. $\ldots \ldots \ldots \ldots$ Mr. K.

A. $\ldots \ldots \ldots \ldots$ Mr. T.

J. .......... Mr. M.

J. ........... $\mathrm{Mr}$.

S. C. ........ Mr. H.

S. C. ....... Mr. S.

Ch. ........... Mr. B.

P. $\ldots \ldots \ldots \ldots \ldots$ Mr. $\mathrm{T}$.

P. $. \ldots \ldots \ldots \ldots . M$ Mr. W

P. .............
Number of Quarts

13.6

23.5

8.4

15.5

8.9

23.8

11.2

24.9

49.4

20.2

10.3

18.8

62.3

8.9

56.4

11.7
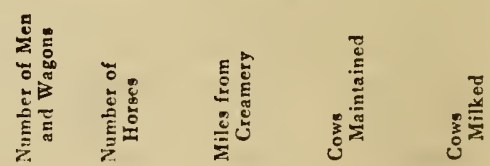

$\begin{array}{lrr}2 & 24 & 8 \\ 21 / 2 & 23 & 17 \\ 1 & 9 & 5 \\ 3 & 9 & 6 \\ 3 & 12 & 12 \\ 21 / 2 & 10 & 8 \\ 31 / 2 & 10 & 10 \\ 4 & 11 & 11 \\ 3 & 16 & 9 \\ 11 / 2 & 16 & 6 \\ 11 / 4 & 12 & 4 \\ 3 / 4 & 16 & 6 \\ 2 & 18 & 16 \\ 23 / 4 & 3 & 3 \\ 21 / 2 & 24 & 17 \\ 21 / 2 & 25 & 13\end{array}$


Table number 7 contains a number of very interesting observations on individual patrons at several of the creameries. The first example in the table is interpreted to mean that Mr. B. at Creamery $\mathrm{S}$, who maintains 24 cows and milked 8 of them, drove two miles with two horses to bring 29 quarts of milk to the creamery, and similarly throughout the table.

There may be many answers to the implied criticisms of in. efficiency contained in these last two tables, for instance, that a market must be found for a small amount of milk as well as a large amount or that men and horses on the farm especially in winter time have nothing to do anyway. But there is no charge here of inefficiency against all dairymen among whom are many splendid business men. The point that is desired to be made is that there are entirely too many instances of the inefficient use of the time of both men and horses to justify the New York consumer in paying a price for milk which contemplates a profit based upon such methods. It would seem that a well organized farm ought to be able to employ both its men and its horses to more useful purposes even in the winter time, while in the summer there is no question about it. However inefficient the city delivery system may be, it is difficult to find more glaring instances of the extravagant use of men, horses and time than in some of the cases above cited.

The transportation of milk from the creameries to the city terminals by the railroads has been lately investigated with great care by the Interstate Commerce Commission for the purpose of fixing freight rates and, although inefficiencies exist therein, as for example, in the case of less than carload lots of milk, this matter has practically been settled by the Commission and it will not now be particularly profitable to discuss it. The railroad terminals supplying New York City are more or less fixed and while the cost of transportation of milk from New Jersey, where most of the terminals center, to the more remote plants of Brooklyn, is an expensive matter either with horses and trucks or automobile trucks, both the dealer and producer are virtually bound by the situation as it is and neither of them is to blame for any inefficiencies that may exist in this part of the delivery system.

But a most interesting field for inquiry is the matter of city retail deliveries and our discussion will here be limited to almost altogether to retail milk sold in bottles. According to Department of Health figures, the average number of quarts of milk received in New York City for the month of November, 1917, was 1,627,127. Of this amount 598,671 quarts were delivered daily from retail wagons in bottles. There were engaged in this service 4,978 retail wagons which showed a distribution from each of 121 quarts according to the above figures. This is not a fair average of the amount of milk sold on these wagons and if it were, it would be entirely indefensible. The capacity load under favorable conditions for the average milk wagon is about 432 quarts, although several 
of the routemen claim that they have delivered with comparative ease between 500 and 600 quarts and one man who is perhaps too optimistic, thinks that he could deliver on his route as high as 700 points including quarters of cream. It would be very easy to estimate the number of wagons required to make a New York City milk delivery, each wagon carrying capacity loads and to fix this as the standard of efficiency. But there are very many modifying circumstances which a careful examination of the matter including personal conferences with many route drivers in various sections of the city have brought forth. 


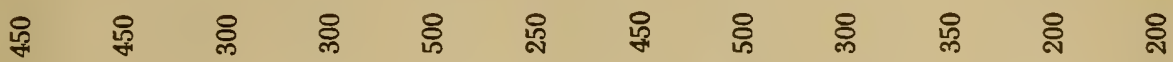
冬 \& \& \& \&

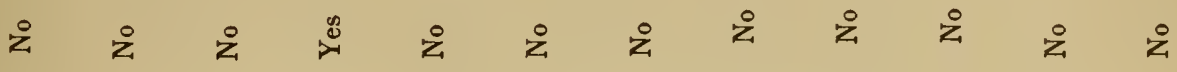

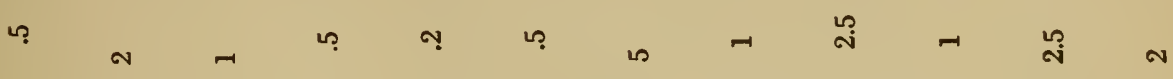
\& $00000 \approx 000$ - นู

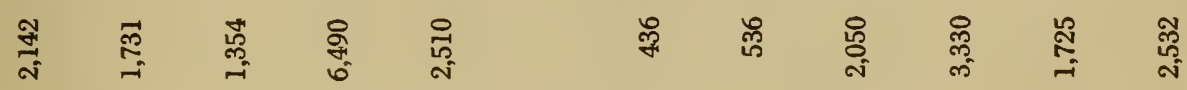

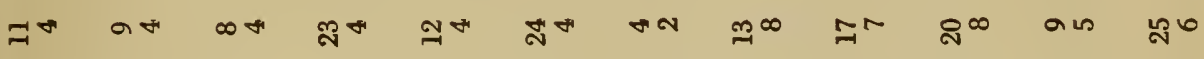

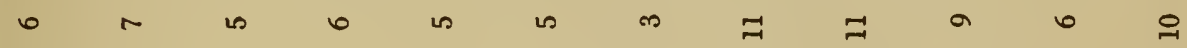

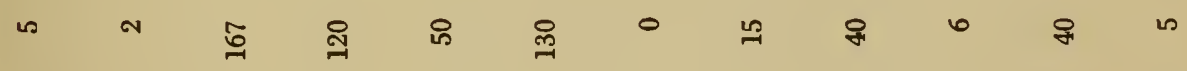

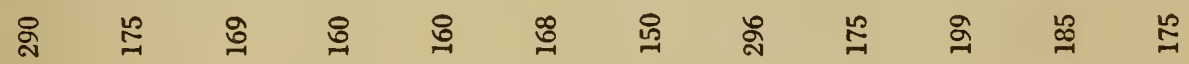

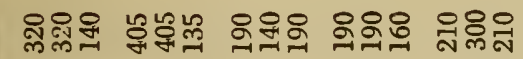

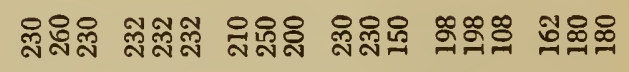
ก ๆ
กับ
$\stackrel{\sim}{\infty}$
$\infty \infty \infty$

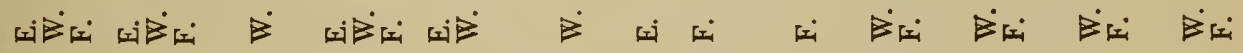

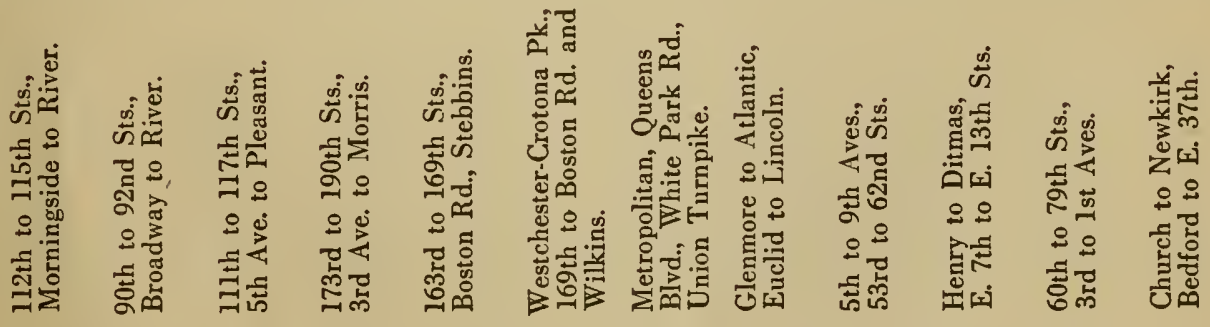

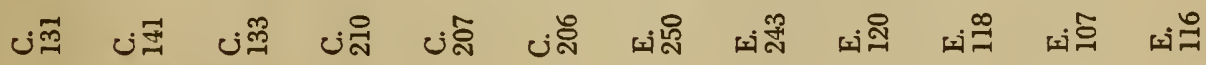




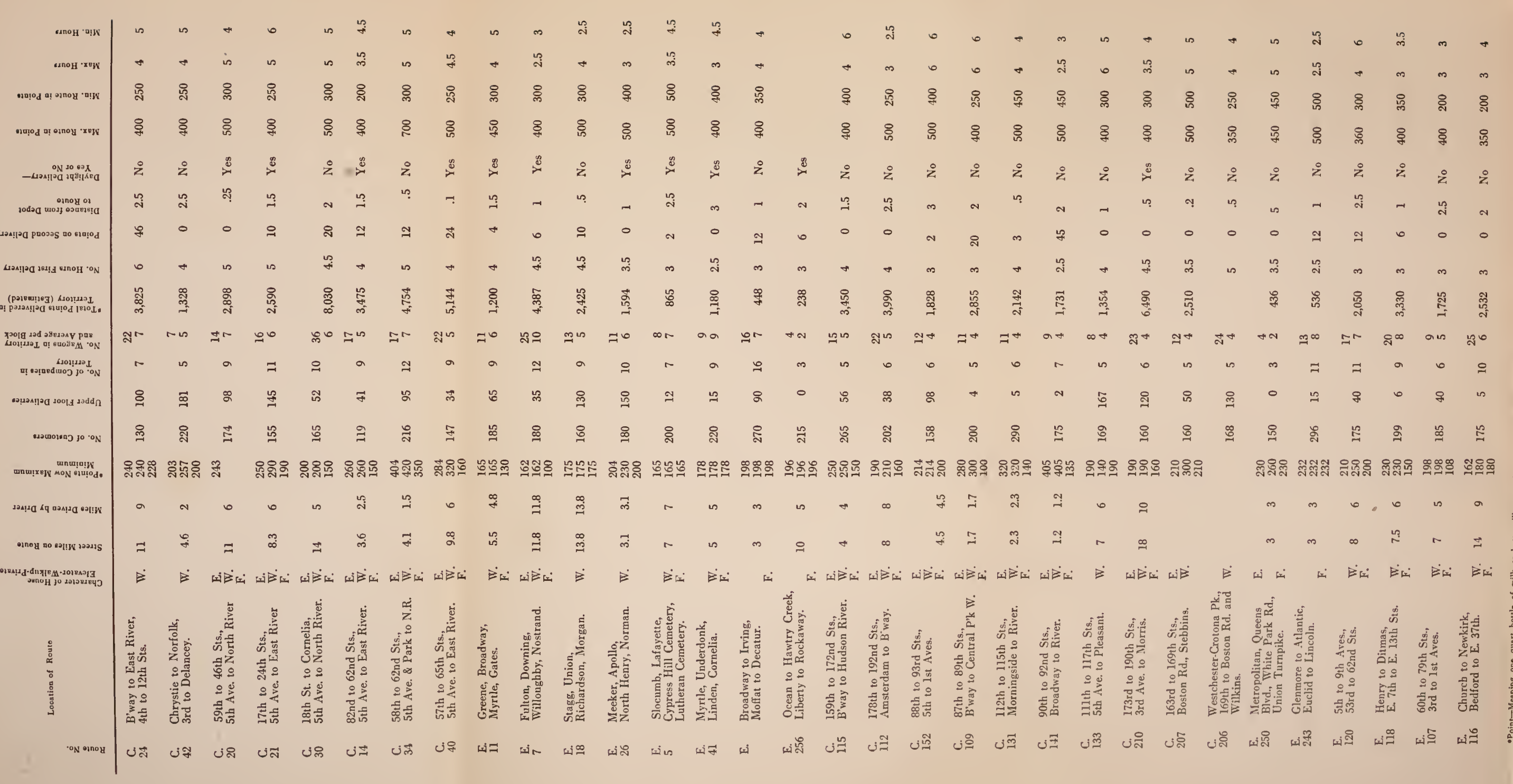



Table 8 is prepared from notes taken at these conferences in the month of December, 1917. Many of the milk companies consolidated about this time, but this table shows the situation very much as it had existed for several years past and before the routes of the consolidating companies were merged with one another as could have been done where duplicate routes existed.

There are many things to be taken into consideration in the delivery of milk. Among these are the character of the houses in the neighborhood in which the delivery is made and the number of quarts each customer takes; for instance, it is one thing to make deliveries to some of the houses in the Fifth Avenue section where from 30 to 50 quarts are often delivered to one customer and where extra quart customers are the rule and quite another thing to deliver in some sections of the East Side where the customers take a small amount of milk and most of the houses are without elevators, requiring the driver in many instances to climb five flights of steps in order to serve a single customer with one quart or even a pint of milk. It is still different in the sections where detached houses prevail.

Again some routes are concentrated more than others. Many of those of the big companies cover but a few city blocks, while most of the routes of the smaller companies are large in extent, one route, as will be seen in the table, covering more than 13 street miles. It will readily be seen that with large customers and concentrated routes anything but a capacity load is an evidence of inefficiency in the delivery system, while in the outlying territory of Brooklyn and Queens such a route does not obtain even where the greatest efficiency is practiced. Table 8 , therefore, endeavors to picture the situation with reference to the character of the houses, the extent of the routes, the amount of milk delivered on each, at the time the data was gathered, and estimates of the maximum and minimum deliveries on the route, the number of companies operating in the territory in question, the number of duplicate delivery wagons on each block, the number of upper floor deliveries, the length of time for the first delivery and the number of points on the second delivery. It will be seen that in no case were there 17 delivery wagons on any block and probably there never was such a number. On the other hand, it is obvious that from 4 to 10 wagons on each block is not economical.

To contemplate a really efficient delivery system, capacity loads so far as they are consistent with reasonable hours and the physical ability of the driver to perform the work of delivery and to make his collections would seem to be the starting point. By a capacity load is here meant as many quarts of milk as can be loaded and carried with safety on an ordinary retail milk wagon. In order. therefore, to ascertain how the different localities, character of the houses, size of customers and concentration of population both in the city and on each route would affect capacity loads, the following questions were asked and answered by each one of the drivers inter- 
viewed. (1) If you had the contract at a fair compensation per quart for delivering all the milk in the best part of your present territory, no other milk company delivering there, (a) how many quarts would you take out per wagon, (b) how long would it take you to make the delivery? (2) If you had a contract for delivering all the milk on the worst part of your territory, (a) how many quarts would you take out per wagon, (b) how long would it take you to make the delivery? The answers to these questions are very interesting and the best opinion on the subject in the city, namely, that of the milk drivers themselves, is reflected in the table. As will be seen in estimating the situation on the maximum routes, there are very few drivers who would not take out a capacity load. On the minimum routes, reflecting the very worst delivery conditions, most of the drivers would take out loads which are considerably larger than the actual amount taken out when the table was compiled, or in fact taken out when their routes were at their best.

The views of the drivers on the daylight delivery system were illuminating as bearing upon that proposed reform. Of the 32 drivers questioned on the matter, 11 were in favor of daylight deliveries and 21 opposed to it. Most of those favoring such delivery were drivers on routes where traffic conditions were not congested. The majority of those who opposed the idea did so on the grounds, first, that in the day time traffic conditions were against it; second, that drivers could not obtain the use of the elevators; third, that it would subject them to the necessity of listening to complaints and entering into conversations with customers which would take a great deal of their time. Most of the drivers opposed the second deliveries as wasteful of time and labor. These second deliveries are of two kinds, where the driver makes a second delivery from the company delivery depot or where he makes a return call during the course of his original delivery. There is no question but what habit enters largely into the demand which causes this particular type of inefficiency.

Without question the city delivery of milk is a great field for saving in time and labor of both men and horses. If a milk company would deliver 100,000 quarts of milk per day with a few less quarts on each route wagon than would pay for the labor of the driver, the maintenance of the horse and the up-keep of the equipment, that company could not survive and would obviously be in a worse financial position than a company with a few well organized routes whose deliveries approached the capacity of each wagon.

It should need no argument to convince one that a great number of small companies duplicating one another's territory cannot operate a New York milk delivery efficiently and that a few large com. panies would serve the consumer much more economically providing the customer could get a portion of the benefit of the savings made by such concentration of the delivery system. Here, then, if at any place, is where an intelligent supervising public authority could do 
a splendid work by aiding, after a thorough study of the matter, in re-districting the city in such a way as to be helpful both to the milk companies and to the public.

In the city of Philadelphia a few years ago, milk was selling at 8c per quart, while in New York it was selling at 9c per quart. The Philadelphia milk companies in every way showed as high a degree of prosperity as those of the New York companies and yet the original cost of the milk was about the same. The writer surveyed the Philadelphia delivery situation and found that most of the larger companies were operating in distinct sections of the city, where outside of a little competition from a few smaller companies, they were in a position to organize the delivery on a very efficient basis. The result was that their routes were larger than the New York routes and even at the lower price charged the consumer, an equal or even greater amount of profit was realized per wagon.

Greater New York would probably present greater problems in the matter of establishing delivery districts than would Philadelphia. At the moment the attitude of many of the organized milk drivers is against large loads so that the New York dealers cannot be charged with entire responsibility for small loads. Suggestions have been made from time to time that the problem could be solved by contract deliveries, but these are clearly impracticable while the milk companies are privately owned because there could be no way of preserving the individual character of the companies and protecting their individual rights under such a system. On the other hand the greatest argument for municipal ownership lies in the unrestricted efficiencies that could be introduced into city deliveries. If such ownership for delivery purposes could be assumed without incurring very grave and tremendous responsibilities in other respects, a good organizer could undoubtedly do wonders in introducing effciencies into the deliveries. But so far as this discussion is concerned, public ownership would be advised only as a last resort when every other means of intelligent co-operation between the public and the distributors had failed.

\section{CHAPTER III.}

Inefficiencies in the Control of the New York Mirlk Supply.

The control to be discussed in this chapter is sanitary control, that is, the check which is brought from some outside agency upon one or more of the phases of the milk industry and intended to improve the character of the milk supply in its health and food value. This restraint may have its origin in the Federal, State and Municipal governments, or the control may be of a private nature, as where the milk dealer on his own initiative seeks to obtain a better and richer milk by making it worth the farmers' while to produce it. So far as the New York City milk supply is concerned, national and state governments have exercised but a slight control, leaving this field almost entirely to the municipality. 
The sanitary control of the milk supply has become one of the most important functions of the New York City Board of Health operating largely through its Bureau of Food and Drugs. No function of the Health Department has been performed with more commendable zeal and with better results than its work of sanitary milk control. It has not always been wise in the methods it has pursued, but this is said in the spirit purely of constructive criticism. The Federal Government, which has no power in the matter except as milk may cross state lines, has confined itself to certain general investigations of an educational nature and New York State has largely devoted its activities to the control of the milk supply tributary to the other cities of the state.

With the efficiency that has been manifested by the New York Department of Health, it is just as well for the New York consumer that these other agencies have left the matter largely to the municipality because where there is a conflict of authority and inspections, as has sometimes been the case even with the slight activity of the state department in the New York City territory, the producer is apt to become confused and to lose his respect for such control as is imposed upon him, especially where inspections have not been immediately followed up. Besides each controlling agency has its own standards and the personal equation is apt to vary considerably.

The greatest step forward in the sanitary control of the New York milk supply was that of dividing the milk into the several grades, grade A, grade B, and grade C. This did not necessarily mean that all the milk of any one of these grades was of that grade. In fact, much of the grade B milk could measure up to the grade $A$ standard and even some of the grade $C$ milk might be of the higher grades, but the grading of milk did impose certain sanitary requisites which were valuable in order properly to define sanitary methods. Another sanitary measure of almost equal importance was the requirement that practically all of the milk supply of New York City should be pasteurized, only the certified milk and a very small portion of the A grade being exempt. It may possibly be questioned if pasteurized milk is as valuable in every respect as high grade raw milk, but in a city the size of New York, requiring such a vast supply of milk and where so many lives are dependent upon the elimination of the primary causes of disease, general pasteurization is the only safe and practical theory.

The Board of Health has in the past exercised its control through the use of inspectors, both city and country, and by the em. ployment of its laboratories located in the city. Regulations have been adopted for controlling the milk supply and those engaged in its production and distribution, and score cards prepared for grading the barns and the methods used on the farm, also for the country and city creameries, while a form of report was used for obtaining a knowledge of the sanitary condition of places in the city where milk was sold. 
In general, Board of Health control worked, largely because the Department could bring pressure to bear upon the dealers by excluding their milk from the city if it did not meet its requirements, thus placing the responsibility on the dealers to bring the producers into line as well as themselves. This principle of shifting the responsibility of control to the dealers, while effective for the time being, is subject to considerable criticism; first, because it tends to do just what should not be done, that is, antagonize two of the branches of the industry; second, because it is unfair to the dealer to hold him entirely responsible for that which may be beyond his control; and third, because such a system of public control falls with the break down for any reason, in the control of the dealer, For instance, since the producers through their organization struck for a higher price for their milk and were successful, the main anxiety exhibited by both the Department of Health and the dealers was for milk. Price has become a controlling factor. It may well be doubted whether the same grip is maintained on the methods of production on the farm today as before the first strike started.

In general, the control of the Department of Health has been criticized in the following respects. To begin with, the farmers have objected to it because of the alleged youth, inexperience and incompetency of some of the inspectors. It is hard to tell just how far this charge is true and how far the Board of Health can be held responsible for it. A man well posted in sanitary matters, may not have had the privilege of being born and raised on a farm and in consequence thereof is liable to occasional mistakes of a practical nature. When these occur it is very damaging to his prestige. Again the farmers complain that all the inspectors who visit them do not conform to the same standards of scoring and instruction. When changes are made in the personnel of the inspectors, variations in judgment are of course likely to occur. Without question, however, occasional changes are not only necessary, but tend to promote efficiency in the inspection system. Many farmers also have learned to appraise lightly the follow up methods of the department's inspectors. This deficiency is probably due to an insufficient number of inspectors operating under the present system and deserves consideration.

There are several criticisms that may be noted, however, which do not originate with the producers, but have to do more with the efficiency of the system in general. First, the hours used for inspection on the farms are usually those between milkings, which means that seldom if ever, are the inspectors present when the methods of the producers may be actually observed. As clean milk is due largely to the use of proper methods on the farm, the lack of direct observation here is hurtful. The inspectors' work is a special work and should be done at times when the opportunity is given for complete observation of everything pertaining to the purposes of the inspection. 
Another criticism is that of a lack of intensive inspections. By this is meant a type of inspection that goes to the bottom of the situation in some locality or particular as where the same milk is followed from the cow to the consumer, comparing the methods used in the various stages of the milk's progress to the consumer, with the increase in bacteria count at each stage as it is handled. By providing for more thoroughgoing work of this kind, many real contributions may be made to sanitary milk control. Third, the lack of proper follow up methods on the farm is a real criticism which should be met by doing as much work along this line as is possible and without any previous notice of any kind, thus at least creating the apprehension in the producer's mind that another immediate inspection may be on the way. The follow up work at the country creameries has generally been very good and the results have been in proportion, but the creameries are more accessible and the work requires fewer men. Fourth, the lack of uniformity in the character of the inspections. This criticism should be met by standardizing the methods of inspection and the values on the score cards. This will promote the effectiveness of the inspections and will add to the constructive character of the work done by enabling valuable comparisons to be made between results obtained in various parts of the country. Regularly held conventions of inspectors will also tend to stimulate more uniform and thorough inspections.

The above criticisms have been directed at the inspection system, but there is another method of control used by the Board of Health, that of the laboratory. The present method of employing the laboratory consists of testing for bacteria and butter fat in the city laboratories on samples taken both in the city and country. The number of bacteria in the milk, as found by the laboratory tests, indicates its cleanliness and the amount of butter fat, its richness. There is no particular difficulty in testing for butter fat in the city laboratories, but trouble has been experienced in getting correct results in testing for bacteria, samples of milk taken in the country, not because the means are not at hand for properly refrigerating the samples of milk taken for analysis, but on account of dirty pipettes and sample bottles and in certain cases improper care being taken of the samples in transit so that the results do not speak the truth. Much irreparable damage may thus be done. 
TABLE IX

\begin{tabular}{|c|c|c|c|}
\hline $\begin{array}{c}\text { Department Count } \\
1 .\end{array}$ & $\begin{array}{c}\text { Official } \\
\text { Farmers' Company Count } \\
\text { Creamery }\end{array}$ & $\begin{array}{r}\text { Company } \\
\text { Tested Milk }\end{array}$ & $\begin{array}{l}\text { Unofficial } \\
\text { Laboratory Co }\end{array}$ \\
\hline $\begin{array}{r}2,000 \\
15,000 \\
4,500 \\
1,600 \\
8,000 \\
3,500\end{array}$ & $\begin{array}{r}1,700 \\
27,000 \\
1,200 \\
1,800 \\
6,200 \\
4,200\end{array}$ & & $\begin{array}{r}3,200 \\
10,300 \\
3,800 \\
2,900 \\
3,500 \\
3,300\end{array}$ \\
\hline $5,600 \mathrm{Av}$. & 7,133 Av. & & 4,500 Av. \\
\hline $\begin{array}{r}7,200 \\
8,200 \\
7,500 \\
10,100 \\
10,500 \\
8,700 \\
9,000 \\
9,700 \\
5,400 \\
7,800 \\
7,000 \\
7,300\end{array}$ & $\begin{array}{c}\text { Receiving Vat at Creamery } \\
9,800 \\
10,200 \\
11,700 \\
9,300 \\
11,000 \\
10,600 \\
8,100 \\
9,200 \\
6,200 \\
5,000 \\
6,500 \\
8,300\end{array}$ & Tested Milk & $\begin{array}{r}8,800 \\
8,700 \\
9,700 \\
12,000 \\
3,400 \\
6,100 \\
5,200 \\
4,400 \\
4,700 \\
4,100 \\
3,600 \\
4,300\end{array}$ \\
\hline $8,200 \mathrm{Av}$. & 8,742 Av. & & $6,500 \mathrm{Av}$. \\
\hline
\end{tabular}

3. Bottles for Shipment at Creamery Gr. A Raw

\begin{tabular}{lrr}
8,500 & 6,700 & 10,800 \\
9,800 & 8,000 & 12,900 \\
9,000 & 11,900 & 11,800 \\
8,000 & 16,700 & 14,400 \\
4,600 & 5,100 & 3,400 \\
4,200 & 1,000 & 4,500 \\
9,700 & 8,900 & 6,200 \\
5,600 & 5,900 & 3,700 \\
8,700 & 7,600 & 9,100 \\
8,700 & 8,600 & 7,500 \\
9,300 & 9,700 & 11,800 \\
9,000 & 9,600 & 8,100 \\
\hline 7,925 Av. & 8,309 Av. & 8,766 Av.
\end{tabular}

4. Farmers' Cans at Creamery (Untested)

$\begin{array}{r}1,200 \\ 4,500 \\ 5,000 \\ 2,200 \\ 1,400 \\ 1,200 \\ 58,500 \\ 14,000 \\ 1,000 \\ 1,700 \\ \hline 9,070 \text { Av. }\end{array}$

\begin{tabular}{rr}
1,400 & 3,500 \\
4,800 & 4,600 \\
4,100 & 3,800 \\
1,500 & 1,900 \\
1,600 & 1,300 \\
1,000 & 900 \\
53,200 & 56,000 \\
14,900 & 18,400 \\
800 & 1,200 \\
1,700 & 1,300 \\
\hline 8,500 Av. & $9,290 \mathrm{Av}$.
\end{tabular}


Department Count Official . Company Count Company. Laboratory Count

5. Receiving Vat at Creamery (Untested)

40,000
30,000
25,000
57,000
25,000
30,000
22,000
28,000
12,400
10,000
18,000
12,000

25,783 Av.

\begin{tabular}{l}
5,200 \\
3,500 \\
2,000 \\
1,300 \\
5,000 \\
9,500 \\
\hline
\end{tabular}

4,416 Av.

400

2,000

1,200

900

1,500

4,000

1,667 Av.

1,300

2,000

800

800

4,000

1,500
39,100

37,800

9,200

39,600

28,300

41,100

23,000

29,000

12,600

10,200

8,400

10,000

24,175 Av.

6. Outlet Heater at Creamery

\begin{tabular}{rr}
4,400 & 3,500 \\
2,200 & 7,200 \\
1,000 & 1,900 \\
800 & 1,500 \\
2,800 & 1,500 \\
5,600 & 1,100 \\
\hline 2,834 Av. & 2,783 Av.
\end{tabular}

7. Outlet Holder at Creamery

5,000

1,400

400

1,000

1,700

5,900

$2,500 \mathrm{Av}$.

8. Outlet Cooler at Creamery

1,500

2,000

400

400

11,600

4,000
39,800

32,700

35,000

32,000

14,700

12,900

18,300

38,700

9,200

10,000

3,700

4,400

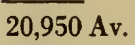

600

900

200

400

600

400

$517 \mathrm{Av}$.

1,400

1,200

700

300

2,500

3,600

1,734 Av.

3,316 Av.

1,618 Av.

9. Bottle for Shipment at Creamery Gr. A Past.

$\begin{array}{r}800 \\ 3,500 \\ 6,000 \\ 1,200 \\ 1,400 \\ 900 \\ 400 \\ 600 \\ 3,500 \\ 3,500 \\ 2,500 \\ 2,000 \\ \hline 2,191 \text { Av. }\end{array}$

1,200

1,200

1,200

300

600

600

600

500

1,400

800

1,800

2,000

$1,018 \mathrm{Av}$.

2,200

1,900

700

5,800

900

400

500

200

1,900

2,200

3,000

1,900

$1,800 \mathrm{Av}$. 
Official

Unofficial

\begin{tabular}{rcc} 
Department Count & $\begin{array}{c}\text { Company Count } \\
10 .\end{array}$ Grade A Raw at Hoboken ir Bottles, same as aboratory \\
at & 3 \\
9,100 & 6,100 & 7,000 \\
17,100 & 15,200 & 11,700 \\
16,500 & 26,800 & 23,700 \\
10,000 & 20,300 & 8,500 \\
4,500 & 5,900 & 9,800 \\
5,000 & 4,500 & 2,400 \\
7,500 & 5,000 & $10,600 \mathrm{~B}$ \\
9,000 & 7,300 & 9,100 \\
10,000 & 8,400 & 10,300 \\
7,100 & 6,800 & 9,300 \\
8,800 & 8,200 & 9,000 \\
9,300 & 9,400 & 9,100 \\
\hline
\end{tabular}

9,498 Av. $\overline{10,334}$ Av. $\overline{10,042}$ Av.

11. Grade A Past. at Hoboken in Bottles, same as 9

1,500

12,700

$300 \quad 11,500$

$2,500 \quad 3,000$

$1,500 \quad 12,700$

$1,200 \quad 1,000$

$400 \quad 500$

$600 \quad 400$

$100 \quad 1,000$

$2,200 \quad 1,300$

$1,700 \quad 1,400$

$2,200 \quad 1,200$

$2,200 \quad 2,400$

1,367 Av. $\overline{4,092}$ Av.

9,500

9,700

12. Various Cases Grade Raw at Hoboken

7,500

8,900

9,600

10,100

8,700

13,000

11,500

11,000

14,500

12,400

12,800

12,700

12,500

14,400

16,500

13,600

19,200

10,300

17,400

12,800

18,600

$\overline{11,492}$ Av. $\overline{13,442}$ Av.

13. Various Cases Grade $A$ Past. at Hoboken

11,500

15,200

3,400

11,900

16,000

20,900

17,000

21,700

16,000

spr.

15,500

1,100

900

1,000

1,000

5,500

500

1,000

123,000

3,000

3,300

2,000

700

1,400
1,300
1,400
800
200
700
700
2,000
1,500
2,200
2,400
900
1,292 Av.
30

10,100

14,017 Av.

11,917 Av.

2,500

5,700

8,400

2,500

2,600

1,800

1,400

3,600

3,600

1,800

3,800

5,000

3,568 Av. 


Department Count Official Company Count Company Laboratory Count

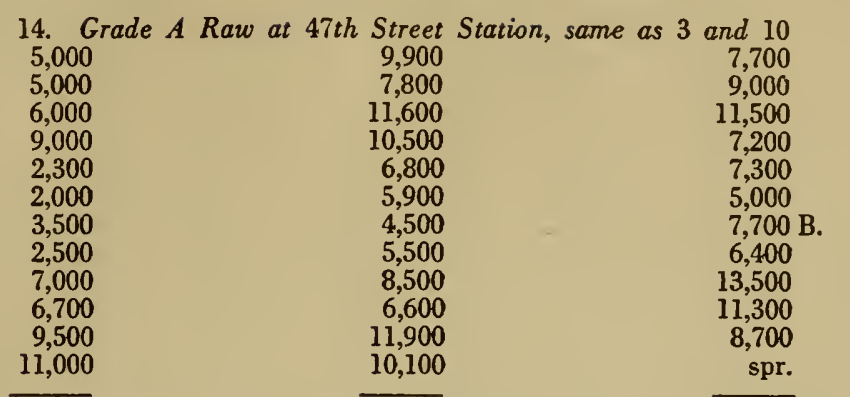

$5,792 \mathrm{Av}$.

8,384 Av.

8,664 Av.

15. Grade A Past. at 47th Street Station, same as 9 and 11

\begin{tabular}{rr}
700 & 800 \\
600 & 600 \\
600 & 800 \\
2,000 & 1,200 \\
800 & 500 \\
600 & 900 \\
700 & 800 \\
500 & 500 \\
3,500 & 1,400 \\
1,500 & 1,500 \\
2,500 & 2,200 \\
3,000 & 1,600 \\
\hline 1,418 Av. & 1,766 Av.
\end{tabular}

2,900

1,900

3,000

2,200

900

1,100

$3,000 \mathrm{~B}$.

4,200

7,000

2,500

5,800

2,500

16. Grade A Past. Various Cases at Station

3,084 Av.

\begin{tabular}{rr}
2,400 & 1,800 \\
1,000 & 2,100 \\
2,200 & 3,000 \\
2,500 & 3,200 \\
100 & 500 \\
1,300 & 1,000 \\
900 & 600 \\
200 & 400 \\
1,800 & 2,100 \\
1,700 & 1,400 \\
2,500 & 2,300 \\
3,500 & 2,000 \\
\hline
\end{tabular}

$1,675 \mathrm{Av}$.

1,292 Av.

600
9,700
spr.
spr.
800
1,700
2,500
1,100
3,600
3,800
spr.
spr.

2,975 Av.

The official counts designated above were made from the same samples in the laboratory of the Board of Health in New York City, one set by the representative of the Company, the other by a representative of the Health Board. Practically all of the unofficial counts were made in the country laboratory of the milk company by the company bacteriologist. Those of the unofficial counts marked " $B$ " at the side were made in the city laboratory of the milk company.

These counts, while seeming to vary somewhat to those not familiar with bacteriology, really show a remarkable similarity, which argues strongly for the laboratory test as an index of the cleanliness of milk when the methods are similar and when carelessness in the taking and transportation of the samples is guarded against or eliminated by the use of country laboratories. 
The following table is the result of an investigation caused by a controversy over the correctness of the bacteria test of samples taken at a certain New York country creamery and is most interest. ing as showing the reliability of the laboratory test as a means of ascertaining the number of bacteria in milk and of the probability of reasonably uniform results under proper conditions.

The Board of Health had made the charge that the counts at a certain Grade A creamery were very high. Inasmuch as the same milk which tested high in bacteria in the Board of Health laboratories was running reasonably low in the country laboratory maintained by the Company which owned the creamery, it became plain either that the methods of testing in use at the country creamery were wrong or at least different from the methods used in the laboratories of the Board of Health, or that the samples were not properly iced and preserved in their shipment to the city laboratory. Since their country laboratory man had received part of his education in the Board of Health laboratory, the natural assumption by the milk Company was that the Board of Health counts did not reflect the true situation.

The Department of Health very generously acquiesced in a joint investigation in which duplicate samples should be taken at various stages of the progress of the milk through the creamery, in its course to the consumer and in the consumer's hands, under the joint supervision of both the Company and the Board of Health. It was also provided that the official testing should be done in the city by both the city and company bacteriologists working independently, that the results should be checked by them, and that every phase of the taking, icing, transporting and testing of the samples should be most carefully done and checked by the two interests. While the unofficial counts in the Company's laboratory, as shown on Table 9, were not provided for in the plan, these counts were made with the same care as the official counts in order that the Company might have a further check on the official investigation. Thus the work of three laboratories was available in the investigation. There was a remarkable uniformity in results, no wide variations appearing in the counts of any of the four laboratories except in one case under 13 where a sample tested 123,000 by the department's bacteriologist but only 2,000 bacteria by the Company's representative and 3,000 in the Company's unofficial laboratory test. This investigation very conclusively pointed to the fact that laboratory results may be reliably uniform when the methods and standards of testing are the same and where care is used throughout the process, and certainly tended to confirm the Company's contention that the original department samples were not properly cared for either in icing or in their transportation.

While the same results might probably be obtained wherever the same degree of care is used as in the above investigation, such care is not to be expected in the ordinary course of the inspector's 
work. Therefore, it would seem that if the Board of Health would encourage country laboratories by making it worth while for the companies to maintain them, many propitious results might be expected. As has been seen, it would eliminate questions that might arise by reason of improper icing of samples. Unspeakable hardship to a milk company which is not in a position to protect itself as happily in the case of the one in our illustration, may easily grow out of such carelessness. By approving the use of country laboratories this hardship could be prevented. If the Board of Health would provide to a certain limited extent for coaching the country laboratory men in the Board of Health's methods of testing, a wonderful means of exercising supervisory control could be provided. The work of these laboratories properly supervised would be practically sufficient as an inspection policy for such companies as maintained them and would also be an incentive for other companies to install them in order to escape the annoyances of the more frequent inspections. No step taken by the Board of Health would give it such effective control of the milk supply and be so easy of administration and so economical in the use of inspectors. For it would leave them practically free to center their work in those districts which neither maintained laboratories nor were advanced in the sanitary production of milk.

Much valuable help has been contributed to the sanitary control of the New York milk supply by private welfare organizations, among which the New York Milk Committee and the National Commission on Milk Standards, stand pre-eminent. Much of the initial activity and efficiency of the Board of Health has been due to the urgings of the Milk Committee. The adoption of standards was originally proposed by the National Commission on Milk Standards, which still retains its organization for the purpose of promoting the adoption of standards by other cities in the country. The work of such organizations, when constructive and comprehensive in its nature, is very valuable. The tendency, however, is for them to pick out one particular interest of the industry for exposure and criticism without taking into consideration that to assail unduly one of its branches may have a detrimental effect upon the whole industry.

Perhaps the most successful and permanent type of control is that which takes its origin in the private interests of the industry itself. Certain of the progressive companies of New York City have made the beginnings in co-operation with the producers by giving premiums for certain desired results on the farm. For instance, a premium has been given for barn score, for butter fat, for low bacteria tests as shown by laboratory counts. The basis for these premiums has often been faulty but the tendency has been in the right direction. It is by stimulating this spirit of co-operation and eliminating the theory of coercion by the dealer over the producer that the Health Department may hope to get the best results in control through the milk dealers. 
In its unwillingness in times past to co-operate especially with the milk dealers, the Health Department has been less justified perhaps than in any other part of its program. In the first place, certain regulations have been passed without consulting the milk dealers and many times without scientific bases. There is also a vast difference between the tests that are made in the laboratory and tests that have a basis co-extensive with the industry. Regulations founded on laboratory data may not always be successfully applicable to the industry as a whole. A few years ago a regulation was passed providing that milk should be pasteurized by heating it to 145 degrees and holding it for thirty minutes. This regulation was not based upon experiments conducted in the industry. The dealers were not consulted. Many of the dealers would have been more than willing to co-operate with the Department in making a series of experiments which would have fixed a practicable basis for a pasteurization regulation. Those dealers who complied with the new regulation when passed found that their milk had lost commercial value. The cream line was impaired and in many cases the taste was affected. Against the protest of the dealers this regulation was kept in force for several months until finally the Department, seeing the necessity, made an experiment in the various plants with the pasteurizing machinery of the dealers and found that the dealers were right in their contention, and changed the regulation, thus finally doing what should have been done in the first instance. Some two years ago a rule was passed by the Board of Health which in effect provided that milk that did not conform to the standard of $\mathbf{8} \%$ solids. not fat, would be treated as adulterated milk. On the earnest protest of the dealers, this regulation, the formulation of which was shown to have no scientific or experimental basis as applied to the dairy situation in New York state, was allowed to lapse.

There is no better place to start the theory of co-operation than in the relations between this agency of public regulation and the various branches of the industry. The sanitary control of the future will never be successful unless this principle of co-operation is adopted. The producers are learning the power and value of organization and they are backed by interests too powerful to stand any great amount of coercion from the city health authorities. The dealers will never advance in prestige nor in efficiency until they are made to feel by those public agencies which deal with them that they are capable, trustworthy and entitled to be consulted in formulating the regulations that are to be imposed upon them.

\section{CHAPTER IV.}

The Promotion of Natural Co-operation.

The facts in the New York milk situation are these:-

1. The producers principally in the state of New York, have formed a combination for their own protection and to control the sale of milk to the city. 
2. The New York distributors encouraged by the inapplicability of the Sherman Law (Federal anti-trust) and the Donnelly Act (New York State anti-combination) to war conditions, have consolidated their interests until there is but little competition among them.

3. The Federal Food Administration, which has been supervising the price paid for milk in New York City, has discontinued its work.

4. At the present time there is no existent agency to adjust the price to be paid for milk to the producers by the distributors.

5. The distributors and producers cannot agree between themselves upon the price to be paid the producer. Conflict over this price may now be a monthly issue.

6. When the distributor is forced to pay more for milk, he as a consequence charges the consumer the additional price in full.

7. The New York milk supply may thus be so curtailed or cut off at any time as to imperil the lives of babies and convalescents dependent upon milk for their proper nourishment or be sold at arbitrary prices.

8. There is almost entire lack of co-operation between the producers, distributors and the present controlling agents in the milk industry.

9. There is more or less inefficiency in the production, distribution and sanitary control of the New York milk supply so that it suffers thereby in quantity, quality and price.

What is to be done? It will be our purpose here to suggest and discuss three methods of handling the matter, any one of which will probably find supporters according to their economic viewpoint, although everybody must agree that the present situation is intolerable. These methods are:-

1. The promotion of natural co-operation between producer, distributor and controlling agent.

2. Public regulation by a state commission.

3. Public ownership.

But first let us consider the results that may be obtained by the promotion of co-operation between the producers, distributors and controlling agents in the milk industry and by the use of efficient business methods and organization throughout the industry. Before the abnormal conditions created by America's entrance into the war New York City was receiving a first-class milk supply in quantities sufficient for the public demand and at a very reasonable price. There was a minimum amount of state interference and none of federal. The milk was under fair control without the aid of politics or law except so far as the police power of the state, delegated to the Board of Health, enabled it to pass and enforce the necessary regulations upon those elements of the industry under its jurisdiction, 
which, however, did not include the producers directly. Why, then, was it possible to control the production of milk? Because New York City was a good milk market, the best one open to producers. Cash was paid for the milk at least once and sometimes twice a month and many conveniences were furnished by the dealers such as cans and convenient shipping stations. The farmers wanted to sell their milk at the New York dealers' shipping stations. This fact is important. Make the New York milk market a good one, especially let the farmer be paid for what is demanded of him by the public. While New York City was getting its milk prior to the war, it was not paying the price for its demands either to the producer nor to the dealer and the unrest and consequent organization of the producers together with the restraints under which the dealers were operating, were indicative of trouble in the whole business machinery.

At first, neither the regulations nor the inspections imposed by the Board of Health were onerous and were submitted to without serious question. The city inspectors had no legal right on the farms, but were permitted to do their work because the producers wanted the New York market. However, the regulations began to increase in stringency and the demands of the health authorities to cost money. New barns had to be built, concrete floors to be laid in old barns, ventilation provided, cow barns were prohibited from being used for any other purpose, ice had to be stored, and so on. The price paid to the farmers did not keep pace with the additional cost of production under the new conditions. Premium payments were finally adopted by many of the dealers, but were not effective for two reasons; first, because the premiums were not properly measured and adapted to the situation; second, because the base price was lowered so that the additions to the milk checks did not have the full effect of premium payments. Not until the war market for cheese and condensed milk appeared and the producers had become thoroughly organized, did the price of milk to the producer become better and then the change was made after a show of compulsion that in many respects made the matter worse than ever. A more concrete diagnosis of the case with suggested remedies follows.

First, a false notion that the price of bottled milk to the consumer should be a fixed one, winter and summer, regardless of the economics of production.

The fact that for a number of years before the war the price of milk in New York City was fixed at 9 cents throughout the year, is only another evidence of the close connections between the milk business and what are generally regarded as public service functions. But, in the case of milk, owing to the great differences in the amounts and cost of production at various seasons of the year, such inelasticity of price tended to hide from the consumer that there was such a thing as the cost of production and delivery, while the dealer in 
order to make up for losses which he experiences in the winter months, endeavors to buy his milk as cheaply as possible at all seasons of the year. It is also less expensive to deliver milk when the weather is good than when the streets are blocked with snow and ice, and certain routes in summer are so small that they are operated at a loss. However, delivery costs are subject to more intelligent control than production costs. If the dealer would be permitted to arrange his prices to the consumer so that he could make a reasonable profit in every month of the year, he would be more reconciled to the payment of fair prices to the farmer at all times.

Second, the failure of the dealers fairly to recognize effort and expense on the part of the producer in meeting their requirements, and the lack of co-operation between these two interests.

The best way to recognize effort and expense on the part of the producer is to do it directly by the payment of an additional price for the same. But such price should be fairly commensurate with what is required of the farmer, and this naturally implies some standard of measurement. There are at least two bases for premiums, one for the extra physical effort and expenditure made by the farmer to meet the requirements, i. e., sanitary equipment, the use of sanitary methods, small mouthed pails, ice, etc. The second basis for paying premiums should be for results in the cleanliness and richness of the milk ascertained by means of laboratories located at the country creameries. These laboratories should also be used to relate the results with the methods used on the farms, the laboratory through its experts thus becoming the educational center of that particular dairy section, and every effort on the part of the farmer to produce better milk in larger quantities and with more profit to himself should be encouraged. The idea of a local dairy center can be worked most advantageously to create good will and co-operation in the industry. Co-operative buying of cow feed for the farmers, cow testing, advising better business methods on the farm and the best methods of clean milk production may all become functions of such a center. Herein will lie the best means of control that is open to the Board of Health. It can well afford to extend every aid in its power to the companies who adopt such a policy with the producer. By all means it should encourage the establishment of country laboratories for the purpose of promoting the better control of the quality of milk produced. It can standardize the methods used in these laboratories by giving a certain amount of education in its city laboratories to the men who do this work and, when the country laboratories and centers are once established, it would be excellent policy for the Board of Health to supervise and check the results obtained here, rather than by insisting upon the same number of direct inspections in such dairy sections, as in one that is not thus controlled. This would mean less expense to the Board of Health in its inspection work, better and more economical general control, for it would thus be free to center its inspection force in those districts 
which are more in need of its time and attention. In short, as officially representing the New York public, its work should be co-operative as well as regulatory.

Third, lack of harmony and co-operation between the Board of Health and the dealers.

The time has passed when the milk dealer should be looked upon as an evader of the law. The presumption should be in favor of his honesty and good faith. Much better and more efficient control could be gained by the Board in adopting this attitude towards the dealer and working with him in solving his problems of control rather than by prosecuting him for isolated instances of the evasion of misunderstood regulations. No regulation should be made until it was found to be reasonable and based upon experiment: made on an industrial scale rather than altogether upon laboratory results. The Board of Health representing the city and the consumer should rejoice in the prosperity of the dealer and no regulations should be passed that were not reasonable and did not guarantee a more salable as well as a more sanitary product.

Fourth, a certain amount of interference on the part of the Board of Health in the business plans and individuality of the dealer.

This is not a prominent cause of trouble in the industry, but it is an important consideration. The milk dealer is a business man and should be encouraged to put individuality into his business but without making it impossible for him to comply with the Board of Health regulations. He should be allowed to honestly advertise his product, to put as much character into his packages as possible and in every way to build up the integrity of his organization and his position as a business man.

Fifth, lack of business methods and organization.

This fault, as has been shown in former chapters, is a leading cause of most of the inefficiencies in production, distribution and control. A better understanding of the industry as a whole on the part of each branch, the application of intelligent analysis to specific problems, the use of simple accounting processes and the stopping of losses will do much to put the industry on a more efficient basis.

The foregoing criticisms of the situation and the recommendations made are not purely theoretical. Natural co-operation has already done much that is tangible in certain instances to create vastly improved conditions.

In a certain valley near the center of New York state are three country creameries about four miles apart and on the same railroad line. Each creamery is the center of an ideal farm and dairying section with a list of patrons about equally intelligent and probably above the average in this respect. Two of these creameries were owned by a New York milk company not overly progressive in its methods or its attitude toward its producers. Fortunately, the third creamery fell into different hands. 
In the year 1909 an innovation in country creamery management was here initiated, which is worthy of a prominent place in the history of dairying. The New York Milk Committee, which had been maintaining a number of infant feeding stations in New York City and had been using certified milk for feeding the babies registered therein, promoted a separate project among its friends and contributors known as the New York Dairy Demonstration Company. This was for the purpose first of obtaining a clean milk for its babies at a cheaper price than it was paying for certified milk, thereby enabling it to reach a larger number of infants with the funds at its disposal, and second of demonstrating that an unlimited amount of milk approaching the certified in wholesomeness and cleanliness could be obtained at the lower cost desired. This was to be accomplished by centralizing the more essential requisites of sanitary milk production, by installing a country laboratory for the purpose of relating the results obtained therein with the work done on the farms, and by securing the co-operation of the producers by inaugurating the policy of paying premiums in addition to the prevailing market price of milk which premiums should be based on approved results obtained by them. They hoped at the same time to create a model system of producing clean milk that would be copied by at least some of the milk companies supplying New York City. While this experiment and the country creamery situation growing out of it had its ups and downs, two indisputable facts became apparent, one being that, properly managed, the new theory was practical from both the sanitary and the commercial standpoint, and the second being that no plan of creamery policy ever produced better efficiency results in the matter of quality, quantity and the placement of the product for profit and with a resulting contentment and spirit of co-operation among the producers.

This first conclusion was borne out by the accounting records of the companies operating the creamery, the second one by the following facts. In the month when the dealer who owned creameries 1 and 2 sold his business, creamery number 3 differing only in management from the other two, received 268,342 quarts while creamery number 1 received only 52,704 quarts and creamery number 2, 56,424 quarts, thus demonstrating that natural co-operation is both appreciated by the farmers and is profitable from a business standpoint. After two years' experience under what were supposed to be trying times for the milk industry, creamery number 3 for the same month in 1917 received 377,848 quarts, a gain of $41 \%$. In September, 1916, when the great demand arose among the farmers for more money for their milk, not a complaint was heard among the patrons at this creamery and they were induced with great difficulty to join in the strike because of general satisfaction with their own position. The fame of the movement spread abroad and many farms tributary to the creamery were sold at greatly enhanced prices by reason of the favorable dairy market. Unfortunately, however, this 
plan of creamery management did not find general favor with the New York dealers, for in the face of a steadily growing and apparent discontentment among the producers, they were not inclined to take the movement seriously. It is a noteworthy fact that very many of dealers today find their business interests absorbed by larger and more strongly financed companies or their buying policy controlled by the producer's organization.

Much more probably might have been done toward natural co-operation between the dealers and producers in creamery 3 , but its almost isolated success upon the co-operative theory is simply indicative of the unprogressive business methods that have to a large extent in the past dominated the milk industry. Of course, as has been indicated before, there was little encouragement from the public for a more constructive policy. To be sure, a system of barn score and butter fat premiums was established by some of the bigger com. panies prior to September, 1916, but this system was neither correct in theory nor in the justice of its applications. Such premiums were never generally regarded by the producer as a step toward co-operation, but rather as a part of the just price withheld which had to be doubly earned in order to be received.

During the year 1918, a milk exposition was held in Grand Central Palace, New York City, at which the dairymen, the distributors, the Department of Health, the State Department and the consumers were represented. This show was so great a success that it was voted to make it an annual affair. At such a meeting as this the foundation might well be laid for co-operation.

The demand of the times in all industry is not so much for associations which simply hold annual meetings, read and discuss technical papers and indulge in industrial politics but rather for industrial agencies properly and permanently manned by responsible experts in which all the divergent interests unite to constructively study those problems common to all, to acquaint the public with whatever is of real value in the industry and thus by pooling contributions to eronomically build and promote and indirectly to throw into the background those little differences which, if not properly guarded against, tend to destroy.

There is one common cause, certainly, upon which both the producers and dealers in the milk industry may profitably join, and that is the popularization of the use of milk as a food, not only for babies and children but for people of all ages. Within the past two or three years much scientific work has been done by thoroughly responsible men which shows the comparatively high food value of milk. If the dealers and producers will join hands in a great campaign of publicity many of the petty differences that at present hinder the industry will be forgotten.

There are also men outside the industry who know its problems and are interested in its normal development in private hands. They might be helpful in laying the plans for co-operation. At least it is 
of great importance that those who are engaged in the business in any of its phases awake to the situation and perform their several functions with a better understanding of the importance and dignity of their calling and with greater regard for the rights of the great public they are serving, or face the consequences of possible action on the part of the public for its own protection.

\section{CHAPTER V. \\ Public Regulation by State Commission}

In the last chapter we have outlined a method by which the milk industry as a whole and the separate interests operating in it would be materially helped by the recognition on the part of each of the several interests of the requisites for the healthful existence of the others and by the introduction throughout the industry of co-operation. Instances of successful co-operation in the industry in the past and the lines along which this principle might properly be extended, were pointed out, leading to the conclusion that if the several interests will co-operate naturally and on their own initiative, this will offer the best solution to the ills that beset the milk business. However, the great trouble is that they have not co-operated in the past and may not do so in the future unless some agency outside the industry furnishes the necessary initiative to start the movement. But an agency to perform this function would have to be clothed with sufficient authority and gauged alòng lines broad enough to have the prestige and to command the respect of those engaged in or dependent upon the industry. Such an agency must needs have the power to compel as well as the ability to initiate and must derive its power directly or indirectly from that source which is charged with the duty of protecting the people in their rights, health, and welfare, even to the extent of regulating the business affairs of the private interests which serve them. This source of power is the state itself and the regulating force with which the state is endowed and which it has the power to delegate to a properly constructed agency for the purpose of protecting the people of New York City in their milk supply, is called the police power of the state.

Let us therefore examine the utility and legality of a commission appointed for the purpose, having delegated to it the police power of the state of New York. Such a commission should derive its authority and appointment directly from the state rather than from the municipality, both for the reason that its functions should be exercised not only for New York City, but for the other municipalities of the state as well, and in order that such a commission might have the fullest possible authority over production and the producers who come within its jurisdiction. What we say, therefore, in the matter of its powers and duties over the milk supply of New York City may, though differing somewhat in detail, be said of its powers and duties over the milk supply of the other cities of the state. 
Such a commission might be composed of from three to seven members, there being represented upon it the producer, distributor, consumer, the state and the city. These men should be thoroughly practical and progressive and above all things should be representative of their several interests, on a co-operative basis. The term of their office and the character of their compensation should be such as to attract high-class men to make service on the commission their sole business and to justify them in devoting all their time and energy to its work; and their authority should be final on all jurisdictional milk matters referred to them. Their functions should be investigatory, supervisory, educational and compulsory. The commission should make a thorough inquiry into the methods used in production, their efficiency and purpose. This would involve not only matters of quality, but also of quantity, of the cost of labor, cows, feed, ice, country distribution and handling of shipping and the character of profit demanded in the country. At the city end, it should view the organization, conditions and efficiency of milk delivery, the equipment used, the cost entailed and the final price demanded of the consumer with the nature and amount of the profit involved.

The conditions of demand and supply of the milk market should be studied and considered, the permanency and the regularity of its requirements, the certainty of pay and the adequacy of price; also the capital invested throughout the industry, the efficient construction and placement of pasteurizing plants and the reasonableness and purpose of sanitary regulations. All these investigations should be made on an industrial scale and with the whole industry in mind. The commissioners should be thoroughly familiar with the progressive development of the industry in all parts of the country and should relate and compare this progress with their own work.

Then comes the supervisory and educational part of their work. The commissioners should have the power to license both producers and distributors. With their knowledge of the business based upon broad investigation and a thorough understanding of industrial conditions generally, the proper situation has developed for them to intelligently supervise the industry throughout and to organize and provide various educational media and methods.

Their recommendation and findings made after such a study would be entitled to and would win the respect of all the elements to be controlled, and thus the foundation for taking the initiative in co-operation would be accorded to the commissioners without question. Such a leadership would be a natural one and resort of the commission to its compulsory powers would thus be only occasional, but when necessary to use it, the wilful wastage of good milk by disgruntled producers and the stoppage of New York's milk supply could be summarily dealt with.

The leading aim of this commission should be to reconcile the use of the police power with which it is endowed with the needs and 
development of the industry. If unintelligently applied, the police power may be distinctly repressive and in no way developmental, but if it can be used with the constructive ideal in mind and with a thorough understanding of the needs of the industry based upon practical experience and investigations it may well become the indispensable aid of the public in securing its rights without hurtfully interfering with the full play of that private business initiative which is so necessary to the growth of the industry. If such a commission could bring about successful co-operation, efficient methods of control and insure a reasonable profit to the producers and distributors for the performance of their functions, the New York milk market would become so good as to attract milk from all localities. Our commission could have legal jurisdiction only over the producers in New York State, but the industry governed by such intelligent direction would be so far in advance of the situation in outside states and the market conditions created thereby would become so good that, in order to enjoy its benefits, outsiders would seek the New York market and would willingly submit to any reasonable licensing and inspection requirements demanded by the commission. In other words, the co-operative, intelligently directed part of the industry would dominate the rest. There could be enough milk produced in the State of New York alone to prevent undue hardship in case of any farmers' combination in the outside states. The work of such a commission could therefore insure milk in sufficient quantities and controlled along much broader lines than the city Department of Health has been able to perform this function in the past.

Let us now consider the legal status of such a commission. Can it be appointed under the laws of New York State and can it exercise such powers as would make it the effective instrument of the people for protecting them in their milk supply. There are several positive things it would have to do.

1. Pass and enforce sanitary regulations.

2. License dealers and dairymen and revoke licenses.

3. Enforce inspections.

4. Supervise and regulate milk markets.

5. Supervise and regulate the methods of production and distribution with a view to promoting efficiency.

6. Regulate prices.

But first there are a number of general questions involved which it will be well to answer.

1. What is the nature of the police power of the state.

2. Can the police power be delegated to a milk commission.

3 . Is the police power applicable to the regulation of the milk industry.

4. What are the general grounds for the application of the police power to the milk industry.

In Com. vs. Alger 7 Cush. 53, C. J. Shaw defined the police power to be, "The power vested in the legislature by the constitution, 
to make, ordain and establish all manner of wholesome and reasonable laws, statutes and ordinances, either with penalties or without, not repugnant to the constitution, as they shall judge to be for the good and welfare of the commonwealth. It is much easier to perceive and realize the existence and sources of this power than to mark its boundaries or prescribe limits to its exercise." Judge O'Brien in People ex rel Armstrong vs. Warden of City Prison says, "All business and occupations are conducted subject to the exercise of the police power. Individual freedom must yield to regulations for the public good."

It is said in 8 Cyc. 865, "A legislature cannot, by any contract, divest itself of its power, but it may delegate its power and jurisdiction to courts, municipalities, or committies to adopt police measures," citing Woodruff vs. New York etc. R. R. Co. 59 Conn. 63, where a commission is empowered to enforce change of grade crossings. New York State's most popularly known commission, exercising broad jurisdiction in the City of New York, is the Public. Service Commission, the constitutionality of which was lately raised in Brooklyn Heights R. R. Co. vs. Straus 245 Fed. 132. A Milk Commission undoubtedly could be appointed by state authority endowed with the police power.

Our next inquiry is in regard to the application of the police power to the regulation of the milk industry. As we saw in People vs. Warden above, "All business and occupations are conducted sub. ject thereto." In St. Louis vs. Liessing, I L.R.A. N.S. 921, the Court says, "Perhaps on no one subject has this police power been affirmed so often as the right to inspect and regulate the sale of milk and cream."

In a note to the above, in which many of the leading cases are cited, the annotator commenting says, "The group of cases here reported well illustrate the attitude of the courts generally toward police regulation of the milk supply. The importance of securing to the community at large cleanliness, wholesomeness and purity in so important a food as milk, has led to the very general enactment throughout the country of regulations as to the standard of quality of milk sold, the care and feeding of milch cattle, and the sale of the product. And while such regulations have been frequently assailed upon the ground that they deprive the dairyman and milk vendor of their property without due process of law, or unjustly discriminate against them, the regulations have been sustained with practical unanimity, whether made by the state through the operation of a general statute or by the municipal council through local ordinances. Among the cases cited here are People vs. Cipperly 101 N.Y. 634, People vs. West 106 N. Y. 293, and many others.

Our fourth question, as to what are the general grounds for the application of the police power to the milk industry, is easily answered. In People vs. Warden 183 N.Y. 220, before cited, the Court says, "It may be laid down as a general principle that legisla- 
tion is valid which has for its object the promotion of the public health, safety, morals, convenience and general welfare or the prevention of fraud or immorality." However, the very nature of our subject being a food makes us think instinctively of health, and so it is that the digests are full of cases where milk, its production and distribution have been regulated on the ground of public health. People vs. Kibler 106 N.Y. 321, Bellows vs. Raynor 207 N.Y. 389, People vs. Vandecarr 175 N.Y. 440, State vs. Broadbelt 89 Md. 565, Adams vs. Milwaukee 129 N.W. 518, State vs. Layton 160 Mo. 498, and many others.

We now approach the solution of our specific problem. With the milk commission established, endowed with the police power of the state, will this power be broad enough to cover those positive functions which it will have to perform in order to make it effective. Could a milk commission pass sanitary regulations protecting the quality of milk, creating standards of cleanliness, providing for inspections and licensing of milk vendors to its markets, even those living outside its jurisdiction, and enforce them? Would it have power to regulate its milk market and sales? There are innumerable decisions which support this right of municipalities as against the claim that they deprive the dairyman or the milk vendor of their property without due process of law, or unjustly discriminate against them. It is simply conforming to the general proposition; if you sell milk in my market, you must respect my regulations.

In Bellows vs. Raynor 207 N.Y. 389, the plaintiff engaged in dairy farming and a member of a creamery company claimed that the defendant, Chief of the Division of Sanitary Inspection of New York City, wrongfully entered upon his premises and interfered with his business. The defendant notified plaintiff of certain unsanitary conditions on his dairy farm which if not improved would exclude his milk from the city. Later a letter was addressed to the creamery company in which it was informed that the rules of the Department were still being violated and gave notice not to include plaintiff's milk in future shipments. The Court held that this was a valid exercise of the police power of the Department of Health of New York City, that it is charged by law with the responsibility of preventing pestilence and disease in the city of New York. That its duty is to enforce all laws applicable to the preservation of human life and the promotion of health-that it has the right to exact from all shippers a compliance with such conditions as would reasonably tend to a pure product for the use of its citizens as a condition of permitting its sale in the city of New York. The Court through Judge Gray said, "It is unreasonable to say that the Department of Health in exercising such power renders itself amenable to the charge of exercising an extra territorial jurisdiction." Other cases along the same lines are People vs. Vandicarr 175 N.Y. 440, State vs. Broadbelt 89 Md. 565 , State vs. Nelson 66 Minn., and many others. 
Whatever powers the city or its Department of Health might have in this regard could be delegated to a properly authorized Milk Commission, and vendors of milk outside the state would have to comply with its sanitary regulations before entering the state markets with their product. The sanitary code of the City of New York requiring license for the sale of milk is constitutional; People ex rel Liebeman vs. Vandicarr 175 N.Y. 440, People ex rel Lodes vs. Board of Health 189 N.Y. 187. Inasmuch as the police powers exercised by both a milk commission and a municipality are delegated by the state and their authority is of equal standing, the commission would have the same power to license dealers and dairymen and to revoke their licenses, these not being vested rights.

As to markets and market places, it is said in 28 Cyc. 930, "The authority to establish and regulate markets falls within the police power of the states, which may be delegated to municipal corporations, and is a particularly appropriate subject for municipal regulation, and they may adopt and enforce any reasonable and proper rules and regulations in regard to the market and the business transacted there." This would enable the commission to study and establish municipal milk markets if the interests of the public and the industry demanded it.

All the above matters are supported by well settled decisions which are just as applicable to the work of a milk commission as any other agency of the state. We now come to the consideration of a different type of function, that of supervising and regulating the methods of production and distribution with a view to promoting efficiency and the regulation of prices. The less the manifestation of police power in the exercise of these functions the better. Herein would appear the ability, breadth and good judgment of the commissioners. Herein the opportunity and demand for leadership based on a solid understanding of conditions. An unprejudiced study of the problems of the industry would give the understanding and the foundation for leadership. Then above everything else the decisions of the commissioners must be fair. A process of education in better organization and methods for both production and distribution would be successful in proportion to the faith which those in the business had in the wisdom and fairness of the com. mission. Here co-operation could be initiated.

But something more might be required than mere supervision and education. The commission must have the power to act, apply pressure and enforce its conclusions. Every legal sanction that supports the use of the police power in its other health and welfare regulations would obtain in promoting efficiency of production and distribution where there were likely to be insufficient quantities of milk for the public welfare or where the commission was respon. sible to the people for maintaining a just price for the milk. The commission would find its main authority for supervising and regulating efficiency in its licensing and price fixing powers. This leads to the question, what powers would the commission have over prices. 
The regulation of prices is supported both by historical precedent and legal decisions.

Parliamentary Regulation of Rates.

In $1266 \mathrm{~A}$. D. the great staples like wool and food were regulated. Henry III. regulated the price of bread and ale, according to the price of wheat and barley, and forbade cornering the market. (51 Hen. 3, Stat. 1.)

In 1337 it was made a felony to export wool. (11 Ed. 3, Cap. 1.)

In 1349 butchers, fish mongers, bakers, poulterers and all other sellers of all manner of victuals were bound to sell for reasonable price. (23 Ed. 3, Cap. 1.)

In the Colonies.

In 1635 Massachusetts merchants were forbidden to charge excessive prices. (Mass. Colon. Laws 673, p. 120.)

Chief Justice Waite in Munn vs. Illinois, 94 U.S., 113, said, "In their exercise it has been customary in England from time immemorial, and in this country from its first colonization, to regulate ferries, common carriers, hackmen, bakers, millers, inkeepers, etc. To this day statutes are to be found in many of the states upon some or all of these subjects, and we think it has never yet been successfully contended that such legislation came within any of the constitutional prohibitions against interference with private property."

Continuing, the Court said in the same case, "This brings us to inquire as to the principles upon which this power of regulation rests, in order that we may determine what is within and what without its operative effect. Looking, then, to the common law, from whence comes the right which the constitution protects, we find that when private property is affected with a public interest it ceases to be juris private only." This was said by Lord Chief Justice Hale more than two hundred years ago, in his treatise De Portibus Maris 1 Harg Law Tracts 78, and has been accepted without objection as an essential element in the law of property ever since. Property does become clothed with a public interest when used in a manner to make it of public consequence and affect the community at large. When, therefore, one devotes his property to a use in which the public has an interest, he, in effect, grants to the public an interest in that use, and must submit to be controlled by the public for the common good. . . . But we need go no further. Enough has already been said to show that, when private property is devoted to a public use, it is subject to public regulation. It remains only to ascertain whether the (grain) warehouse of these plaintiffs in error, and the business which is carried on there, come within the operation of this principle. . . . It is difficult to see why if the common carriers or the miller, or the ferryman, or the baker, or the cartman pursues a public employment and exercises a sort of public office, these plaintiffs in error do not." 
It is said in 8 Cyc. 1117, "When a business is of such a nature as to be effected with a public interest, the state may require that charges shall be reasonable, and may adopt measures necessary to secure that result." Dillon vs. Erie R. R. Co., 43 N.Y., suppl. 320, Munn vs. Illinois 94 U.S. 113. In Budd vs. People 143 U.S. 517, it was held that the laws of New York (1888) C. 581, fixing a maximum charge of $5 / 8$ of a cent per bushel for elevating grain is not taking private property without due process of law, but is a valid exercise of the police power, as well in its application to elevators owned by private individuals as to those owned by companies having chartered privileges from the state, since the business as carried on is affected with a public interest and is a practical monopoly.

"A power granted to the corporation of the City of Mobile to license bakers and regulate the weight and price of bread, and prohibit the baking for sale, except by those licensed, is not contrary to the constitution of the state." Mayor of Mobile vs. Vuille 3, Ala. 137.

The following cases have held that it is competent for the legis. lature of a state through the agency of a commission when the welfare of the public is at stake to limit and regulate charges and prices. Carriers.

Commonwealth vs. Inter. Consol. Lt. Ry. Co. 187 Mass. 436

San Antonio Traction Co. vs. Altgelt 815 W. 106-200 U.S. 304.

See American \& English Encyc. Vol. 23 p. 655 and cases cited.

Stone vs. Farmers Loan \& Trust Co., 116 U.S. 307.

Dillon vs. Erie R. R. Co., 19 Misc. 116.

Waldorf Astoria Co. vs. City of N.Y. 212 N.Y. 97.

\section{Water Companies.}

Tampa Water Works Co. vs. City of Tampa 199 U.S. 241.

San Diego Water Co. vs. City of San Diego 118 Cal. 556.

Spring Valley Waterworks vs. Bartlett 16 Fed. 615.

Stockyard Companies.

Cotting \& Kansas City Stock Yards Co., 82 Fed. 839.

Gas Companies.

Richman \& Consolidated Gas. Co. of N. Y. 114 A.D. 216, affirmed 186 N.Y. 209.

Trustees of Village of Saratoga Springs vs. Saratoga Gas, Electric Light \& Power Co., 191 N.Y. 123.

Grain Elevators.

Reversing 122 A.D. 203.

Budd vs. People 143 U.S. 517.

People vs. Walsh, 117 N.Y. 1.

Brass vs. State, 153 U.S. 391.

In Re Annan, 50 Hun 413.

Under the sanction of these decisions, then, could not a milk commission regulate the price of milk? In the language of Justice Waite on Munn vs. Illinois above quoted, "It is difficult to see why if the common carrier or the miller or the ferryman or the baker or the cartman pursues a public employment," prices can be fixed for 
these services, the milk business is not equally in the public interest and equally subject to price regulation.

It would seem, therefore, both in theory and legally, that a properly constituted milk commission would be able to exert a most beneficent influence upon the industry. But if it would properly serve the people in fixing and regulating prices, it must take as its standard an efficiently conducted industry throughout and must be clothed with power both to investigate and compel that efficiency as a prerequisite to granting licenses for entrance to its markets. The main difficulties with the practical carrying out of the idea would be of a political nature. It is not only the up-state dairyman who is in conflict with the city dealer, but there has been for years a division between New York City and the up-state voter. Those state officers who would probably have the appointing power under our scheme would hesitate to take any stand that might be construed as antagonistic to the farmer. While this plan of public regulation by a commission could be so administered as to be a great blessing to the New York State dairyman, it is very likely he would not see it that way.

Then, again, the personnel of the commissioners would have to be right. If politics could be kept out of their appointment and the ideal of service could be brought into their work a splendid economic contribution might be made by them. If politics did enter into their appointment and work, the commission would be detrimental to the industry and to the public. Herein lies the rub.

\section{CHAPTER VI.}

\section{The Case for Public Ownership of the Milk Industry.}

When a business of real public importance can be carried on advantageously only upon so large a scale as to render the liberty of competition almost illusory, it is an unthrifty dispensation of the public resources that several costly sets of arrangements should be kept up for the purpose of rendering the community this one service. It is much better to treat it at once as a public function, and, if it be not such as the government could beneficially undertake, it should be made over entire to the company or association which will perform it on the best terms for the public.-John Stuart Mill.

We come now to consider the proposition that the City of New York should acquire the milk industry, not upon the basis of the socialist, whose economic reasoning would justify the public ownership of any industry, but upon the grounds that are usually given and legally maintained, under our present theories of private ownership and so-called capitalistic economy, for the ownership by municipalities of public utilities and public service agencies. We have previously alluded to the fact that those who are engaged in the various functions of the milk business, either in producing or distributing, are performing a public service. In the former chapter we have presented legal opinion to the effect that those who devote 
their property to the milk business are devoting it to a use in which the public has an interest, and therefore in effect grants to the public an interest in that use, and must submit to be controlled by the public for the common good. We must now consider whether that interest of the public is so great as to justify its assuming the ownership under the law just as it does for instance in the case of municipally owned water works.

There is something incongruous, perhaps, in comparing and likening the public ownership of the water supply to that of the milk supply. But there is much that is similar in the two cases, and in selecting water for comparison, we have not gone to the shady borderland of propositions for municipal ownership, but have chosen something on which the reasoning and legal decision are well settled.

"The general power given a municipal corporation in respect to police regulations, the preservation of the public health, and the general welfare includes the power to establish municipal waterworks." Ellinwood vs. Reedsburg, 91 Wis. 131, 64 N.W. 885.

In Grace vs. Hawkinsville, $101 \mathrm{Ga} .553,28$ S.E. 1021, the rule is recognized that a municipal corporation has power, under a general welfare clause in its charter, to construct and maintain waterworks necessary to provide citizens with water for drinking and other domestic purposes.

"A supply of water for municipal purposes, as well as for the use of its inhabitants, is a city purpose within a constitutional provision forbidding the incurring of indebtedness except for city purposes." Re Comstock, 25 N.Y. S.R. 611, 5 N.Y. Supp. 874.

"A municipal corporation does not lose its municipal character, and become a private or business corporation, by erecting waterworks and supplying its citizens with water." Lehigh Water Co.'s Appeal, 102 Pa. 515.

In Heqnembourg vs. City of Dunkirk 49 Hun 550, the Court, in holding that the construction and operation by a city of a plant for the purpose of supplying electric lights to the city and its inhabitants is a city purpose, says, "Numerous cases have arisen in which large and extensive waterworks had been established for the purpose of supplying cities and villages with pure, wholesome water. In such cases, the water has been furnished to private consumers at fixed rates and the power to do this has been sanctioned by the courts as one properly exercised by the municipal government, pure and wholesome water being recognized as necessary to preserve the public health, and in various cities gas works have been established in which light has been supplied by the municipality to private residences at a fixed charge as well as used for the lighting of the streets."

Dillon in his work on Municipal Corporations on page 2118, says, "The furnishing of a supply of water, not only as protection against fires and for sanitary purposes, including sewers, but also for 
the individual use of the inhabitants of a municipality, has always been recognized as a proper public and municipal purpose, based upon the inherent and palpable necessity of the case and the customs of thickly settled communities."

Let us look at milk and water side by side.

\section{First Parallel.}

\section{Water}

1. Municipality uses it.

2. Universally used by inhabitants.

3. Constantly used.

4. Essential to public health.

5. No substitutes.

6. Must be clean and pure.

7. Will carry infection.

8. Quality must be controlled.

9. Main sources outside city.

10. Private interests may sell under special authorization.

11. Business tends toward monopoly.

12. Usually requires power of eminent domain.

13. Makes peculiar use of public streets, necessitating special grant.

The points that are generally sustained by the courts for the municipal ownership of any business are, first, business tends toward monopoly; second, public nature and purpose of the business, and, third, public welfare. In the above parallel these three points seem to be as well covered in the case of milk as of water, the main difference between the two being that water is cheaper than milk and the fact that we are more accustomed to think of water in connection with municipal ownership than milk. This is partly because the importance of milk as a carrier of disease and the necessity for the public supervision of its wholesomeness and quality has only been appreciated during the past decade.

In the case of Sun Printing \& Pub. Asso. vs. New York 8 App. Div. 230, 238, 40 N.Y. Supp. 607, 611, affirmed in 152 N.Y. 257, 37 L.R.A. 788, 46 N.E. 499, the Court employed the following language: "The true test is that which requires that the work shall be essentially public and for the general good of all the inhabitants of the city. It must not be undertaken merely for gain or for private objects. Gain or loss may incidentally follow, but the purpose must be primarily to satisfy the need or contribute to the convenience of the people of the city at large. Within that sphere of action, novelty should impose no veto. Should some inventive genius bye and bye 
create a system for supplying us with pure air, will the representatives of the people be powerless to utilize it in the great cities of the state, however extreme the want and dangerous the delay? Will it then be said that pure air is not so important as pure water and clear light? We apprehend not."

In Pond on the Control of Public Utilities, p. 28, it is said: "The courts are of the opinion that it is not only within the power of the cities, but that it is their duty, to keep themselves free to accept for their own use and to provide for their inhabitants new inventions and superior agencies as they arise, and that cities are not to be restricted to the providing for the strict necessities of their citizens, but that they may also minister to their comfort and pleasure."

Dillon in his work on Municipal Corporations, 2089 says, "The term 'public utility' might, in an extended sense, include the laying out, arranging and regulating streets and highways, wharves, parks, etc., (in State vs. Barnes 22 Okla. 191) but, in the more restricted sense in which it is generally used, its meaning is limited to those enterprises which have for their end, the sale of commodities and the rendition of service, which to some extent are for private advantage or convenience of individual inhabitants.

On page 2100 , he says, "But a complete definition of a "city purpose' is not possible in view of the immense variety of objects which have been found to be necessary to the health and welfare of modern municipalities. (Sun Pub. Assoc. vs. N. Y. C. 152 N. Y. 257. See New York City, Matter of, 99 N. Y. 569.) Each case must depend largely upon its own facts, and the meaning of these words must be evolved as successive cases arise by a process of exclusion and inclusion in judicial construction." (People vs. Kelly, 76 N. Y. 475.)

On page 2102 , he says, "But a dividing line between what is a municipal purpose and what is not, is in many cases shadowy and uncertain, great weight should be given by the courts to the legislative determination, and its action should not be annulled unless the purpose appears clearly to be one not authorized. (People vs. Kelly, 76 N. Y. 475, 489.) While city purposes will usually find their development within the municipal limits, such purposes are not necessarily limited to a work or expenditure within the city."

\section{Another Case Sustaining Public Ownership-Ice.}

In Holton vs. Camilla $134 \mathrm{Ga}$. 560, the Court holds that, "The operation of an ice plant by the municipal authorities of the city of Camilla, in connection with the electric light and waterworks plant, for the purpose of furnishing ice to the inhabitants of the city, is not in violation of the Constitution of this state, or otherwise illegal." The answer of the defendant, which was introduced in evidence and considered upon the trial, states that, "In the hot climate in which the city of Camilla is situated ice is necessary for the comfort, health and convenience of its inhabitants. If this is true, why should 
not the city be permitted to furnish ice to its inhabitants? And if the furnishing of ice to its inhabitants is conducive generally to their health, comfort and convenience, it is certainly being furnished for a municipal or public purpose. It is a well-known fact that one of the main uses to which ice is put is the cooling of water for drinking purposes; and when it is used for this purpse, if impure, it is as apt to be deleterious to the consumer as any other impure water. Why then in the exercise of its police power, may not a city guard against impurities in the ice as well as the water used by its inhabitants?"

Cases Held Not to Warrant Public Ownership.

Coal and Wood as Fuel

Opinion of Judges, 15 L. R. A. 809, "The purchase by the city or town of coal and wood as fuel, and the resale thereof to its in. habitants, is not a public service which can be authorized by the Legislature. We are not aware of any necessity why cities and towns should undertake this form of business, any more than many others which have always been conducted by private enterprise; and we are not called upon to consider what extraordinary powers the Commonwealth may exercise, in extraordinary exigencies, for the safety of the state or the welfare of the inhabitants."

Re Municipal Fuel Plants 60 L. R. A., 592, the Court holds, "Municipalities have authority to provide fuel for paupers; but they cannot be given power by the legislature to buy and sell fuel in competition with private enterprise, although it is scare and high in price and the cost to consumers may be thereby reduced, unless there is such a scarcity as to create a general and wide-spread distress in the community, which cannot be met by private enterprise. We are not called upon to consider whether the legislature would deem it advisable, if it has the power, to authorize cities and towns to build storehouses in which to keep large quantities of fuel in anticipation of a possible famine. In regard to the fourth of the possible consequences, - a condition in which the supply of fuel would be so small, and the difficulty of obtaining so great, that persons desiring to purchase it would be unable to supply themselves through private enterprise, - it is conceivable that agencies of government might be able to obtain fuel when citizens generally could not. Under such circumstances we are of opinion that the government might con. stitute itself an agent for the relief of the community, and that money expended for the purpose would be expended for public use."

So, in Baker vs. Grand Rapids, 142 Mich. 687, 106 N. W. 208, it was held that, "The use of a fund by a municipal corporation for the purpose of buying and selling coal in the time of scarcity of fuel was not a public use, and was therefore unauthorized."

On the other hand, in Jones against the city of Portland 245 U. S. 217, it is held that a law of Maine authorizing any city or town to establish and maintain a permanent wood, coal and fuel yard for the purpose of selling wood, coal and fuel to its inhabitants at cost does not take the property of tax payers for private 
uses in violation of the fourteenth amendment, especially where the highest court of the state has declared such purpose to be a public one.

The legislature of Louisiana, on the 8th of March, 1869, passed an act granting to a corporation, created by it, the exclusive right, for twenty-five years to have and maintain slaughter-houses, landings for cattle, and yards for inclosing cattle intended for sale or slaughter within certain parishes including the city of New Orleans and a population between two and three hundred thousand people and prohibiting all other persons from building, keeping, or having slaughter-houses, landings for cattle, and yards for cattle intended for sale or slaughter, within those limits. It was held that this grant of exclusive right or privilege guarded by proper limitation of the prices to be charged and imposing the duty of providing ample con. veniences with permission to all owners of stock to land and of all butchers to slaughter at those places, was a police regulation for the health and comfort of the people within the power of the State legislatures. Slaughter House cases 16 Wallace 36.

\section{Second Parallel}

\section{Milk}

1. Municipality uses it for hospitals, etc.

2. Universally used by inhabitants.

3. Constantly used.

4. Essential to public health.

5 . No substitutes.

6. Must be clean and pure.

7. Will carry infection.

8. Quality must be controlled.

9. Main sources outside city.

10. Private interests sell.

11. Business tends towards monopoly.
Coal or Wood for Fuel

1. Municipality uses it (inconsiderable unless for gas and electricity).

2. Less than milk.

3. Less than milk.

4. At times.

5. Yes, natural gas.

6. No.

7. No.

8. No.

9. Main sources outside city.

10. Private interests sell.

11. No, although monopoly was chief reason for the Maine U. S. Sup. Ct. decision.

It is easily seen from the above parallel that coal and wood as fuel lack several of the requisites for municipal control which both milk and water possess, i.e., "essential to public health," "quality must be controlled" and "business tends toward monopoly," so that even if the Courts have held against coal and wood for public control, it only tends to support the doctrine that each case must depend largely on its own facts.

Assuming then, that the milk industry conforms to so many essential requirements for municipal ownership as announced by American legal decisions, we believe there is a good case on the law 
of the matter, conferring the power on New York City to own the industry, especially if it is supported by legislative enactment.

We come now to the various ways in which municipal ownership and control may manifest itself.

PLAN 1

(a) Municipal ownership of city delivery equipment, pasteurizing plants and milk markets.

(b) Private ownership of production sources.

PLAN 2

(a) Municipal ownership of city delivery equipment, pasteurizing plants and milk markets.

(b) Gradual organization and control of enough of production to dominate the rest.

PLAN 3

(a) Granting monopoly privilege to a private milk company already organized and equipped to give city service.

(b) Regulating enough of production by law and through police power to assure supply.

The first plan above outlined has been often suggested. It would enable many efficiencies to be inaugurated, first, in the city delivery of milk such as carrying capacity loads on the milk delivery wagons or zoning the city; second, by the proper organization and placement of pasteurizing plants whereby overhead charges could be saved by operating properly located plants to their capacity, and third, by bringing unity of policy into the city milk market situation. For instance, the infant feeding station idea could be extended by opening these stations all over the city so that whosoever desired, whether they had children in the family or not, could go to the stations for milk and thus save to themselves the extra cost of wagon delivery. Of course, there might be some sanitary objections to this process, requiring the regulation of both the manner of handling the milk in the stations and in the hands of the purchasing consumer. The practical carrying out of this idea, however, would make considerable difference in the price to the consumers who would purchase it in this way. The main reason that the stations are not further extended today, is because of the desire of the Board of Health not to interfere with private business enterprise.

Another way that the extension of milk stations would reduce the price to the consumer, would be in saving of bottles which can there be brought under almost perfect control. One has only to look in ash cans, vacant fields and apartment house cellars to understand the appalling losses in milk bottles now borne by the public. This plan, however, would leave the control of production in the same hands as it is today. The producers could strike at the prices paid by the city just as well as at those paid by the milk dealer and there would be no assurance of a continuous supply of milk. On the other hand, by leaving the market control entirely in the hands of the city, the prices could be made so attractive to the milk producer, that pro- 
duction would be stimulated and consequently successful production strikes less likely.

The second plan provides for the same type of municipal own. ership in the city and also for the gradual extension of control over enough of production to insure the city a minimum supply of milk no matter what the organizations of dairymen on the outside might do. In theory, it might be conceived that the city should attempt to produce milk by owning the land and the cows for the purpose. On the theory that such ownership was for a city purpose, the law would probably sustain such action. There are cities in Europe today where the cows and production are publicly owned. But, such a course here would, while presenting the field for a very pretty theoretical experiment in efficient production, cost more money and require more organizing ability than New York City probably possesses. On the other hand, by adopting the idea of the regulating commission such as was discussed in our last chapter, enough of production might be dominated in this way to assure the City of its proper milk supply.

The third plan contemplates the idea of allowing the tendency of monopoly among the milk dealers in the city, to have full play by permitting the consolidation of companies for the purpose of securing the monopoly privilege of supplying the city with milk. This plan would have no advantages over the present situation in protecting the city against production strikes unless the idea of the regulating commission was also adopted to assure the continuous production and supply of milk to the city.

The main attempt that has been made in this study has been to set out the problem as it has appeared to the writer after considerable study and thought, with the idea that some suggestion might be contributed to those who will finally have the burden of solving the milk problem. The writer himself is committed to the theory of natural co-operation and private control of the industry and believes thoroughly that with proper leadership and encouragement from the New York public, the milk industry can be made one of the most interesting, useful and efficient of American industrial enterprises.

The function of government is not business and those engaged in public life will do better in adhering to their proper functions. Politics is never efficient and politics would certainly enter the milk business under general public control. Since both production and distribution are distinct functions of the milk industry, each dependent for industrial health on the other with the consumer entitled to efficiency from both, the first great requisite is the co-operation of producer, distributor and consumer. On this will depend the big. ness and the health of the industry. Upon this bigness and health will depend the profits to those engaged in the industry and the wholesomeness of the product received by the consumer. The real interest of the producer is not production alone, but a healthy milk industry throughout. The real interest of the distributor is not dis- 
tribution alone, but a healthy industry throughout. The consumer's position is not to support one side or the other, but to insist upon the co-operation of both these interests to the end that the public may be better and constantly served with a healthful milk supply. If this is done hearty support should be accorded both producers and dealers alike. 


\section{VITA}

The author was born in Zanesville, Ohio, in 1875. He holds the degree of A.B. and A.M. from Marietta College and L.L.B. from the Ohio State University. He practised law in Zanesville, Ohio, served two terms as probate and juvenile judge of Muskingum County, Ohio, and was United States Commissioner in the Southern district of Ohio. He studied in the Political Science Department of Columbia University under Professors Beard, Goodnow, Giddings, Seager and Smith. He was later connected with the New York Bureau of Municipal Research where he was assigned to special milk investigations in the city and state. For a number of years he was Secretary and Director of the New York milk business which furnished the city infant feeding stations with milk and is now Assistant Secretary of the Metropolitan Trust Company of New York. He has been an occasional contributor to the Educational Review, Scribner's and the New York Times Magazine.

JAMES F. NEWCOMB COMPANY, INC. 
$-$ 


